\title{
Evidence-based recommendations for short- and long-term management of uninvestigated dyspepsia in primary care: An update of the Canadian Dyspepsia Working Group (CanDys) clinical management tool
}

\author{
Sander JO Veldhuyzen van Zanten $\mathrm{MD}^{1}$, Marc Bradette $\mathrm{MD}^{2}$, Naoki Chiba $\mathrm{MD}^{3}$, David Armstrong $\mathrm{MD}^{4}$, \\ Alan Barkun $\mathrm{MD}^{5}$, Nigel Flook $\mathrm{MD}^{6}$, Alan Thomson $\mathrm{MD}^{7}$, Ford Bursey $\mathrm{MD}^{8}$, \\ for the Canadian Dyspepsia Working Group
}

\begin{abstract}
SJO Veldhuyzen van Zanten, M Bradette, N Chiba, et al; for the Canadian Dyspepsia Working Group. Evidence-based recommendations for short- and long-term management of uninvestigated dyspepsia in primary care: An update of the Canadian Dyspepsia Working Group (CanDys) clinical management tool. Can J Gastroenterol 2005;19(5):285-303.
\end{abstract}

The present paper is an update to and extension of the previous systematic review on the primary care management of patients with uninvestigated dyspepsia (UD). The original publication of the clinical management tool focused on the initial four- to eight-week assessment of UD. This update is based on new data from systematic reviews and clinical trials relevant to UD.

There is now direct clinical evidence supporting a test-and-treat approach in patients with nondominant heartburn dyspepsia symptoms, and head-to-head comparisons show that use of a proton pump inhibitor is superior to the use of $\mathrm{H}_{2}$-receptor antagonists $\left(\mathrm{H}_{2} \mathrm{RAs}\right)$ in the initial treatment of Helicobacter pylori-negative dyspepsia patients. Cisapride is no longer available as a treatment option and evidence for other prokinetic agents is lacking. In patients with longstanding heartburn-dominant (ie, gastroesophageal reflux disease) and nonheartburn-dominant dyspepsia, a once-in-a-lifetime endoscopy is recommended. Endoscopy should also be considered in patients with new-onset dyspepsia that develops after the age of 50 years. Conventional nonsteroidal anti-inflammatory drugs, acetylsalicylic acid and cyclooxygenase-2-selective inhibitors can all cause dyspepsia. If their use cannot be discontinued, cotherapy with either a proton pump inhibitor, misoprostol or high-dose $\mathrm{H}_{2}$ RAs is recommended, although the evidence is based on ulcer data and not dyspepsia data.
In patients with nonheartburn-dominant dyspepsia, noninvasive testing for $H$ pylori should be performed and treatment given if positive. When starting nonsteroidal anti-inflammatory drugs for a prolonged course, testing and treatment with $\mathrm{H}_{2} \mathrm{RAs}$ are advised if patients have a history of previous ulcers or ulcer bleeding.

Key Words: Acetylsalicylic acid; Aspirin; Dyspepsia; Gastroesophageal reflux disease; NSAIDs; Systematic review

\section{Recommandations fondées sur des preuves} pour la prise en charge à long et à court terme de la dyspepsie non investiguée en médecine de premier recours : Le point sur l'outil de prise en charge clinique du groupe CanDys

\footnotetext{
Le présent article constitue une mise à jour et une annexe de la revue systématique précédente sur la prise en charge des patients souffrant de dyspepsie non investiguée (DNI) en médecine de premier recours. La diffusion initiale de cet outil de prise en charge clinique insistait sur une évaluation de la DNI échelonnée sur quatre à huit semaines. Cette mise à jour se fonde sur des données récentes issues d'analyses systématiques et d'essais cliniques pertinents.

On dispose désormais de preuves cliniques directes à l'appui de l'approche « tester/traiter » chez les patients qui manifestent des symptômes de dyspepsie non dominés par les brûlures d'estomac, et des comparaisons directes montrent que les inhibiteurs de la pompe à protons donnent de meilleurs résultats que les anti- $\mathrm{H}_{2}$ dans le traitement initial des patients souffrant de dyspepsie Helicobacter pylori-négative. Le cisapride ne fait plus
}

${ }^{1}$ Department of Medicine, Queen Elizabeth II Health Sciences Centre, Dalhousie University, Halifax, Nova Scotia; ${ }^{2}$ Department of Medicine, Université Laval, and the Department of Gastroenterology, Centre hospitalier universitaire de Québec, Pavillon Hôtel-Dieu de Québec,

Quebec, Quebec; ${ }^{3}$ Division of Gastroenterology, McMaster University, Hamilton, and the Surrey Gl Clinic/Research, Guelph, Ontario;

${ }^{4}$ Department of Medicine, McMaster University, and the Division of Gastroenterology, Hamilton Health Sciences Corporation, McMaster Site, Hamilton, Ontario; ${ }^{5}$ Department of Medicine, McGill University, and the Division of Gastroenterology, McGill University Health Centre, Montreal, Quebec; ${ }^{6}$ Department of Family Medicine, University of Alberta, and the Misericordia Community Health Centre; ${ }^{7}$ Department of Medicine, University of Alberta, Edmonton, Alberta; and ${ }^{8}$ Health Sciences Centre, Department of Medicine, Memorial University of Newfoundland, St John's, Newfoundland

Correspondence: Dr Sander Veldhuyzen van Zanten, Division of Gastroenterology, Dalhousie Medical School, Queen Elizabeth II Health Sciences Centre, 1278 Tower Road, Room 928 Victoria Building, Halifax, Nova Scotia B3H 2Y9. Telephone 902-473-1499, fax 902-473-5548, e-mail zanten@dal.ca

Received for publication September 9, 2004. Accepted February 2, 2005 
partie des options thérapeutiques offertes et les preuves relatives aux autres agents procinétiques sont lacunaires. Chez les patients qui souffrent d'une dyspepsie de longue date, dominée par la présence de brûlures d'estomac (c.-à-d., RGO) ou non, une endoscopie unique est recommandée. L'endoscopie devrait aussi être envisagée chez les patients dont les premiers signes de dyspepsie se manifestent avant l'âge de 50 ans. Les AINS classiques, l'acide acétylsalicylique et les inhibiteurs sélectifs de la COX-2 peuvent tous causer la dyspepsie. S'il est impossible d'en cesser l'usage, on recommande leur coadministration avec un inhibiteur de la pompe à protons, du misoprostol ou un anti- $\mathrm{H}_{2}$ à forte dose, bien que les preuves reposent sur des données issues d'études sur les ulcères plutôt que sur la dyspepsie. Chez les patients dont la dyspepsie ne se manifeste pas principalement par des brûlures d'estomac, il faut procéder à un dépistage non effractif de $H$. pylori et instaurer le traitement approprié selon les résultats. Lorsqu'on commence un traitement prolongé au moyen d'AINS, il est recommandé de procéder à des tests et de traiter au moyen d'anti- $\mathrm{H}_{2}$ si les patients ont des antécédents d'ulcères ou d'hémorragies digestives.
$\mathrm{T}$ he Canadian Dyspepsia Working Group (CanDys) has previously reported the development of an evidence-based clinical management tool (CMT) for patients who present with uninvestigated dyspepsia (UD) to the primary care physician (1). The CMT consists of five steps (Figure 1). For three of the steps, treatment recommendations provide the physician with treatment options listed according to strength of the published evidence, with the most effective treatment listed first.

The CMT uses a definition of dyspepsia that includes heartburn and acid regurgitation symptoms that primary care physicians consider part of the dyspepsia symptom complex (1). This is in contrast to the Rome II Consensus Working Party, which considers heartburn and regurgitation to be diagnostic of gastroesophageal reflux disease (GERD) and distinct from dyspepsia (2). There is more recent support for the CanDys definition of dyspepsia. In two studies $(3,4)$ of Helicobacter pylori-positive patients with UD that included the symptom of heartburn, eradication of $\mathrm{H}$ pylori resulted in improvement of the epigastric pain and in the severity of heartburn. In a large Danish population-based dyspepsia study (5) where patients with reflux symptoms were included, heartburn improved in patients who were successfully treated for their $H$ pylori infection. Other data $(1,6,7)$ have confirmed an overlap among dyspepsia and GERD symptoms as defined by Rome II.

The present paper is an extension of the previous work by the CanDys group (1). There are several reasons why an update is necessary. The initial publication of the CMT dealt only with the initial (acute) four- to eight-week management period for UD patients. There is a need for evidence-based recommendations on long-term management. Second, there are new data from primary care-based clinical studies that strengthen the treatment recommendations of the CMT. Finally, certain management questions were not covered in the original CMT, such as once-in-a-lifetime endoscopy in patients with heartburn because of concern about Barrett's esophagus (BE), the role of H pylori in GERD, the use of overthe-counter (OTC) medications, and special situations such as the management of dyspepsia in pregnancy.

\section{METHODS}

The process for the current update was the same as that used for the generation of the original CMT. CanDys is a multidisciplinary group consisting of academic and community-based family physicians, gastroenterologists and pharmacists. A list of relevant topics was generated and reviewed in detail. For each topic, searches were carried out to identify new clinical trials, systematic reviews (meta-analyses) and/or practice guidelines. All identified articles for each particular topic were retrieved and reviewed by individual members. The subsequent findings were presented to CanDys and extensively discussed, including an assessment of the quality of the evidence. Most searches were initiated broadly (ie, BE and review) and, depending on the question, searches were refined further (ie, risk, adenocarcinoma or treatment). Treatment or management strategy searches focused on identification of new randomized controlled trials, clinical trials or cohort studies. Searches were comprehensive; group members reviewed a large number of citations. Potentially relevant articles were retrieved and checked for further relevant references. Based on these searches and discussions, statements were generated as to which, depending on the topic, was a diagnostic or treatment recommendation, and these were subsequently categorized by the group. Finally, the group voted on all statements. This grading process has been previously described in detail (Table 1) $(1,8)$.

\section{PATIENT REFERRAL MANAGEMENT ISSUES}

Evidence for an age cut-off of 50 years to recommend endoscopy

The recommendation for endoscopy in patients over 50 years of age with chronic, stable symptoms stems mainly from expert opinion expressed in practice guidelines. In considering the role of endoscopy, it is important to determine what the findings would be if endoscopy were performed in all patients and whether this would alter management. In the Canadian Adult Dyspepsia Empiric Treatment - Prompt Endoscopy (CADET-PE) study (6), 1040 patients with UD underwent prompt endoscopy within seven to 10 days, without therapy, after presentation to their family physician. The study was designed to provide data on the prevalence of clinically significant endoscopic findings in undifferentiated UD patients. The majority (58\%) of UD patients did have clinically significant findings at endoscopy. Esophagitis was by far the most common diagnosis (43\%), while duodenal and gastric ulcers were found in $2.8 \%$ and $3 \%$, respectively. Esophagitis was more common (55\%) in patients with dominant symptoms of heartburn or acid regurgitation. More important, endoscopic esophagitis was seen in 36\% of patients who did not have dominant heartburn or acid regurgitation. The majority of patients with gastric (55\%) and duodenal ulcers $(69 \%)$ were $H$ pylori-positive. Because symptoms are not good predictors of the endoscopic findings, these data support the significant overlap that exists between dyspepsia and GERD, and argue against the Rome II statement that GERD symptoms define the disease. Finally, the results indicate that endoscopy is unlikely to change medical management and, therefore, it is reasonable to proceed with an empiric trial of therapy as defined in the CMT.

In the CMT, endoscopy is recommended for patients over the age of 50 years who present with new-onset dyspepsia. This recommendation remains unchanged although this age cut-off is largely based on the incidence of gastric and esophageal cancer, which starts to increase significantly over 50 years of age, albeit slowly. Recent data (9-21) confirm that most esophageal and gastric malignancies present with alarm features and, thus, further support that the presence of any alarm 


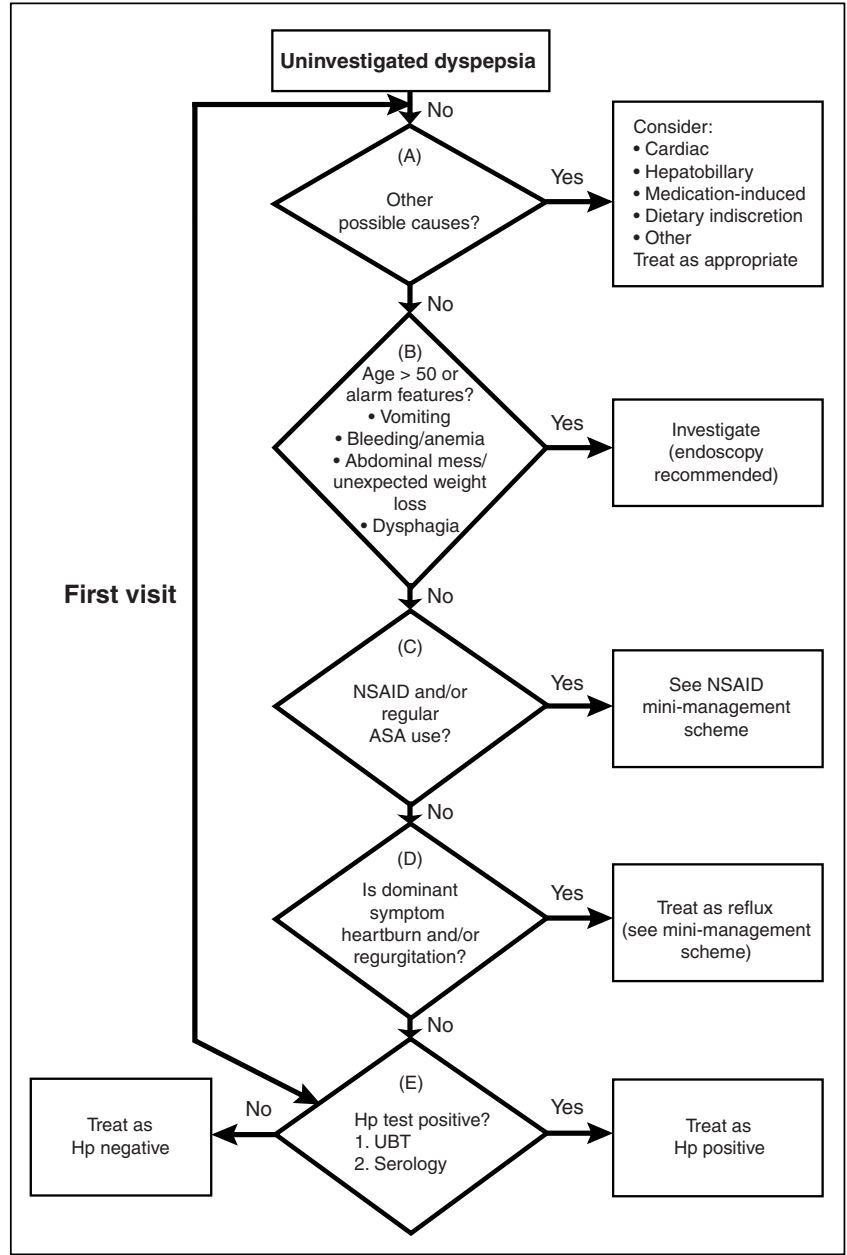

Figure 1) Clinical management tool, 2000. ASA Acetylsalicylic acid; $\mathrm{Hp}$ Helicobacter pylori; NSAID Nonsteroidal anti-inflammatory drug; UBT Urea breath test. Adapted from reference 1

feature (vomiting, bleeding/anemia, abdominal mass, unexplained weight loss, dysphagia) is an indication for endoscopy. There are no randomized controlled data to support or refute an age cut-off of 50 years and, therefore, this arbitrary assignment remains based on expert opinion. The American Gastroenterology Association, American College of Gastroenterology, British Society of Gastroenterology and European Society of Primary Care Gastroenterology recommend endoscopy over the age of 45 years (9-12). The 1998 Dyspepsia Working Party report from the World Congresses of Gastroenterology (13) suggests an age cut-off of 50 years in Western nations. The updated British Society of Gastroenterology guidelines (14) suggest an age of 55 years for endoscopy. The recent Scottish guidelines (15) do not suggest an age cut-off due to lack of evidence; however, they do promote that an $\mathrm{H}$ pylori test-and-treat strategy is appropriate. Undoubtedly, clinical judgement is required (Table 2). In practice, patients with new-onset dyspepsia after 50 years of age compared with those with long-standing symptoms would be considered differently.

Many patients with UD will receive long-term acid suppression. If symptoms persist or recur frequently, it is reasonable to perform endoscopy at least once in the management of the patient's disease to either confirm a suspected diagnosis
TABLE 1

Categorization of evidence, classification of recommendations and voting schema

Voting on recommendations
A Accept completely
B Accept with some reservation
C Accept with major reservation
D Reject with reservation
E Reject completely

Quality of the evidence

I At least one appropriately designed, randomly assigned, controlled trial

II-1 At least one appropriately designed controlled trial without random assignment

II-2 Cohort or case-controlled studies, preferably from one or more research groups

II-3 Substantial or marked results from uncontrolled studies

III Opinions of experts based on clinical experience or descriptive studies

Classification of the recommendations
A Good supportive evidence
B Fair supportive evidence
C Poor supportive evidence but recommendations reasonable on other grounds
D Fair contrary evidence
E Good contrary evidence

Adapted with permission from references 1,8

(eg, esophagitis) or rule out serious underlying disease, especially cancer. Therefore, the authors' suggestion, considering all other factors including age, symptoms, higher-risk populations and physical signs, is that if symptoms have been present (either continuously or frequently recurring) for years, and are without recent change or progression, then endoscopy is likely not required and the short-term CanDys approach may be considered (1). If symptoms are becoming more severe or have recently changed, then endoscopy must be considered.

\section{BE and esophageal cancer}

$\mathrm{BE}$ is considered a complication of chronic gastroesophageal reflux and is a risk factor for esophageal adenocarcinoma. This should be a consideration when discussing the need for endoscopy, specifically in patients with long-standing heartburn. There is evidence for publication bias, with overrepresentation of studies with relatively small sample sizes reporting higher cancer risks $(9,22-44)$. Although the RR of adenocarcinoma (30- to 100-fold) is increased in patients with $\mathrm{BE}$, the absolute risk remains low $(0.4 \%)$, as does the risk of dying from the disease (25).

The prevalence of BE (Table 3 ) does increase with age and is higher in males, especially Caucasians. In the CADET-PE study (6), the overall prevalence of histologically confirmed BE was $2.4 \%$ and $4.1 \%$ in patients with dominant heartburn or regurgitation, respectively. Because the prevalence of $\mathrm{BE}$ is low, it is not necessary to provide early endoscopy for patients with dominant heartburn symptoms. Rather, one might consider endoscopy at a later date (using the presence of reflux symptoms for five to 10 years, severity or ongoing need for acid suppressive therapy as an indication). Because it is difficult to accurately diagnose BE when there is active inflammation in the distal esophagus, it is preferred that endoscopy 


\section{TABLE 2}

Age cut-off: Incidence and clinical considerations surrounding gastric or esophageal cancer

\begin{tabular}{lccc}
\hline Risk consideration & Age (years) & $\begin{array}{c}\text { Incidence (\%) } \\
\text { men/women }\end{array}$ & Clinical consideration \\
\hline Gastric cancer & $<50$ & $0.1 /$ no data available & Chronic stable symptoms for $>5$ to 10 years \\
& 50 to 60 & $0.2 / 0.1$ & Upper gastrointestinal malignancy unlikely \\
& 60 to 70 & $0.4 / 0.3$ & if alarm features are absent, especially if \\
& 70 to 80 & $0.7 / 0.3$ & $<60$ years \\
Esophageal cancer & 80 to 90 & $0.7 / 0.4$ & Is there a good therapeutic response to treatment?
\end{tabular}

Notes

- Gastric and esophageal cancer rates increase after 50 years of age

- Risk is greater in men than women

- There may be increased risk in subgroups such as immigrants from high prevalence regions

- Test of Helicobacter pylori infection due to associated gastric cancer risk

Adapted from references 6,9-15,17-21

\section{TABLE 3}

\section{Barrett's esophagus: Relevant data}

\begin{tabular}{cc}
\hline Definition & A metaplastic change from normal esophageal \\
squamous epithelium to columnar intestinal epithelium. \\
Endoscopically, this is suspected because of a \\
difference in the colour compared with normal \\
esophageal epithelium. The necessary histological \\
hallmark is the detection of intestinal metaplasia in \\
biopsies taken from the lower esophagus. When \\
intestinal metaplasia is accompanied by dysplasia, the \\
risk of malignant transformation is increased \\
Prevalence: \\
Worldwide $\quad$ In all patients undergoing endoscopy, the prevalence \\
literature $\quad$ is reported between 1\% and 3\% \\
In patients with long-standing heartburn, the \\
prevalence of Barrett's esophagus is $3 \%$ to $5 \%$ and \\
in some reports as high as $6 \%$ to $12 \%$, likely in \\
selected patient groups \\
In all patients undergoing endoscopy with heartburn, \\
the prevalence is $0.3 \%$ to $2.4 \%$ \\
In all patients presenting with dyspepsia, the \\
prevalence is $2.4 \%$ to $4.1 \%$ and $5 \%$ in those with \\
literature \\
dominant heartburn and Helicobacter pylori-negative \\
Lifelong proton pump inhibitor, at least standard dose, \\
regardless of the presence of symptoms. Dose titrated \\
up, if required, to achieve adequate symptom control \\
Endoscopic surveillance, in accordance with \\
established guidelines
\end{tabular}

Adapted from references 6, 10,17-19,28

be performed while the patient is on maintenance acid suppression therapy for his or her GERD symptoms.

While $\mathrm{BE}$ is managed by the specialist, it is important for the primary care physician to understand the issues as they apply to patients presenting with dyspepsia with or without dominant heartburn. In Canada, esophageal cancer is rare (in $2002,1.4 \%$ of the 68,600 new cancer cases in men and $0.6 \%$ of the 65,400 new cancer cases in women) and is still less frequent than gastric cancer (27). Over the past two decades, the incidence of all esophageal cancers has not changed. The overall prevalence (five per 100,000) of esophageal cancer (including both squamous and adenocarcinoma) remains low, and did not increase for men and women from 1972 to 1999 (27). However, the incidence of esophageal adenocarcinoma has markedly increased and now represents greater than $50 \%$ of all new esophageal cancers. In contrast, the incidence of esophageal squamous carcinoma has decreased. There is an increased risk (OR 7.7) of adenocarcinoma at the gastroesophageal junction in those patients suffering from long-standing reflux symptoms, although the absolute risk, as noted above, is low (28). In contrast, the OR for adenocarcinoma originating in the cardia was 2.2 (28). In that study (28), increased severity, frequency (greater than three times per week), and long duration (greater than 10 to 20 years) of symptoms increased this OR to 16.4 to 20.

Although BE is a risk factor for esophageal adenocarcinoma, most patients presenting with cancer were not known to have $\mathrm{BE}$ before their cancer diagnosis (23). Given these data and the evidence for publication bias with over-reporting of the cancer risk, the importance of identifying BE may be overestimated. Nevertheless, there is limited evidence that, with surveillance endoscopy every few years, adenocarcinoma formation in patients with $\mathrm{BE}$ is detected earlier and may lead to better outcomes $(16,44-47)$. Recent economic analyses, however, suggest that the yield of surveillance endoscopies is low and may not be cost-effective (48).

The American College of Gastroenterology guidelines (10) on surveillance for patients found to have BE are often followed; ie, endoscopy one to two years after the initial endoscopy and, if no dysplasia is detected after two endoscopies, then endoscopy every third year thereafter. It seems likely in the future that the screening interval may be extended because most patients with dysplasia will be detected early on. More frequent surveillance is required if dysplasia has been detected because of the link between dysplastic changes and malignant transformation but this requires specialist care. It is important that if high-grade dysplasia is found, confirmation of the finding by a skilled gastrointestinal (GI) pathologist is generally recommended. If high-grade dysplasia is confirmed, referral to a centre specialized in treatment of esophageal cancers should be considered.

Treatment of BE aims to optimize acid suppression because there is compelling evidence that $\mathrm{BE}$ is a complication of 
chronic acid reflux (29). Treatment with a proton pump inhibitor (PPI), usually life long, is recommended as the standard of care for patients with BE (49). Most patients with BE do not complain of dyspepsia symptoms such as heartburn and regurgitation, and this may be due to mucosal insensitivity. However, PPI treatment should be maintained in these patients even if they are asymptomatic. Similarly, if a patient is taking once-a-day PPI and continues to have symptoms, a dose increase can be considered. A PPI rather than an $\mathrm{H}_{2}$-receptor antagonist $\left(\mathrm{H}_{2} \mathrm{RA}\right)$ is recommended, given the superior level of acid suppression produced by PPIs. There is very limited evidence that PPI therapy may lead to a decrease in the length of BE or prevent its progression. There is one randomized controlled trial (50) comparing omeprazole with ranitidine over two years which demonstrated that the PPI induced a small but significant partial regression of $\mathrm{BE}$. There is no convincing evidence that antireflux surgery may help prevent the progression of $\mathrm{BE}$ to carcinoma. Referral of patients with BE for surgery is not currently the recommended standard of care (51).

\section{Recommendations}

1. In patients with long-standing or severe (five to 10 years, more than three times per week), dominant symptoms of heartburn and regurgitation and/or patients requiring long-term maintenance therapy with antisecretory medications $\left(\mathrm{H}_{2} \mathrm{RA}, \mathrm{PPI}\right)$, a once-in-alifetime endoscopy is recommended.

$\begin{array}{ll}\text { Voting on recommendation } & \mathrm{A} / 9 \\ \text { (level/vote) } & \mathrm{B} / 2 \\ & \mathrm{C} / 1^{*} \\ & \mathrm{D} \text { to E/0 } \\ \text { Level of evidence } & \mathrm{II}-2 \\ \text { Classification of recommendation } & \mathrm{B}\end{array}$

*One vote was cast for accepting with major reservation $(\mathrm{C})$; this individual felt that a once-in-alifetime endoscopy could be performed at a later point in time.

2. Once a diagnosis of BE has been made, guidelines for endoscopic surveillance should be followed. Current recommendations suggest a repeat endoscopy every three years if no dysplasia is found after two consecutive annual endoscopies.

$\begin{array}{ll}\text { Voting on recommendation } & \mathrm{A} / 6 \\ \quad & \mathrm{~B} / 6 \\ & \mathrm{C} \text { to E/0 } \\ \text { Level of evidence } & \mathrm{II}-2 \\ \text { Classification of recommendation } & \mathrm{C}\end{array}$

3. The management of a patient with BE should include optimal acid suppression therapy, currently achieved with a PPI using the dose that maintains complete symptom resolution.

$\begin{array}{ll}\begin{array}{ll}\text { Voting on recommendation } \\ \text { (level/vote) }\end{array} & \mathrm{A} / 0 \\ & \mathrm{~B} / 12 \\ & \mathrm{C} \text { to E/0 } \\ \text { Level of evidence } & \mathrm{II}-3 \\ \text { Classification of recommendation } & \mathrm{C}\end{array}$

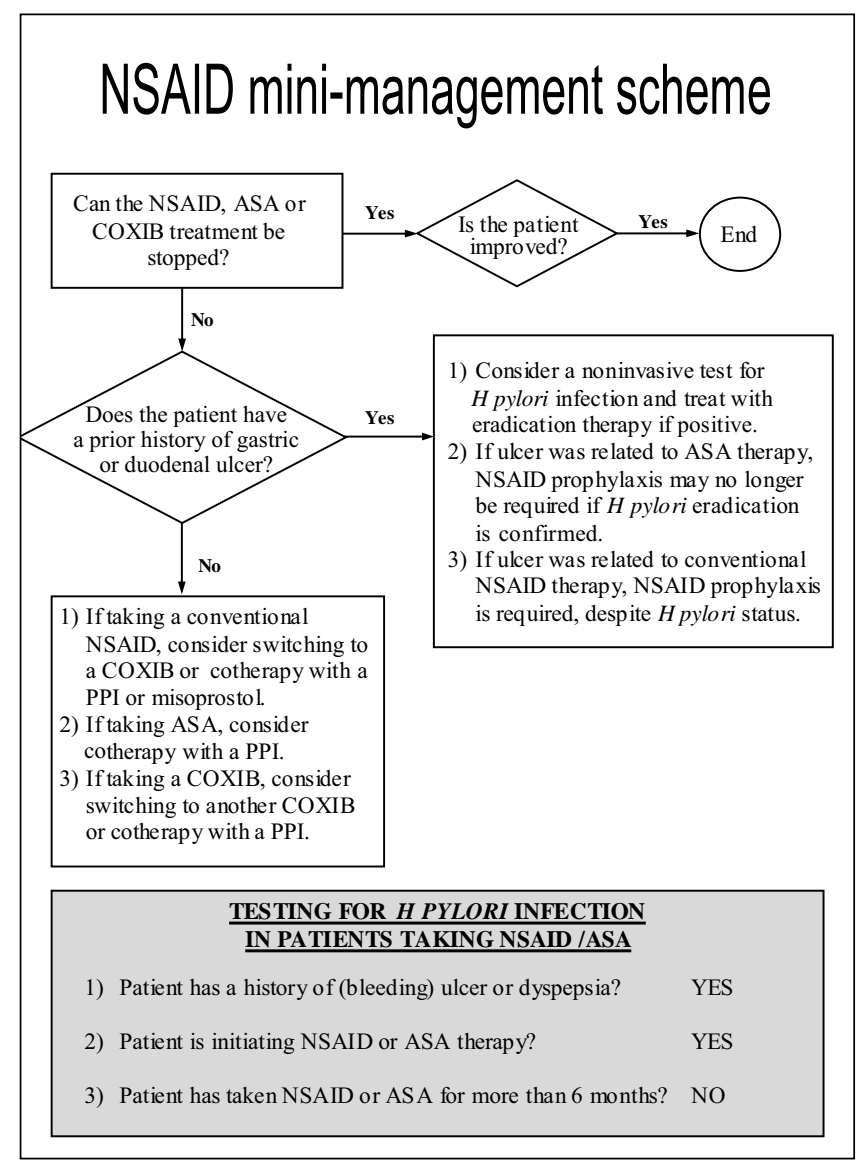

Figure 2) Nonsteroidal anti-inflammatory drug (NSAID) minimanagement scheme. ASA Acetylsalicylic acid; COXIB Cyclooxygenase-2-selective inhibitor; PPI Proton pump inhibitor. Adapted from reference 1

\section{ACETYLSALICYLIC ACID, CONVENTIONAL NONSTEROIDAL ANTI-INFLAMMATORY DRUGS AND CYCLOOXYGENASE-2- SELECTIVE INHIBITORS}

The third step of the CMT deals with acetylsalicylic acid (ASA) or nonsteroidal anti-inflammatory drug (NSAID) use. The recommendations for NSAIDs remain unchanged except regarding areas involving $\mathrm{H}$ pylori (Figure 2).

NSAIDs, ASA and cyclooxygenase-2-selective inhibitors Cyclooxygenase (COX)-2-selective inhibitors (COXIBs) have recently come under intense scrutiny because of evidence that their use may be associated with an increased risk of cardiovascular events. This has led to withdrawal from the market of rofecoxib; recent reports also question whether celecoxib and perhaps valdecoxib and naproxen have similar adverse cardiovascular side effects. It seems likely that use of all COXIBs and perhaps some NSAIDs will be re-evaluated in the near future. The following recommendations are suggested for patients currently taking or being considered for COXIB or NSAID therapy.

Conventional NSAIDs are known to increase the incidence of gastric and, to a lesser extent, duodenal ulceration, presumably through inhibition of the COX-1 enzyme along with the desired inhibition of the COX-2 enzyme that is needed for its anti-inflammatory effect. COXIBs selectively inhibit the 
COX-2 enzyme but spare the activity of the COX-1 enzyme; as a result, it has been postulated that there is considerably less ulcerogenic potential with the COXIBs (52). The benefit of COXIBs appears to be substantial for ulcers, but is much less for dyspepsia symptoms in comparison with conventional NSAIDs $(53,54)$. Indeed, there continue to be questions regarding the use of COXIBs, NSAIDs and ASA and the development of dyspeptic symptoms. All these agents can cause dyspepsia and/or ulceration; however, no clinical data exist to guide management for scenarios where patients are switched from conventional NSAIDs to a COXIB $(55,56)$. Data on the frequency of NSAID-induced dyspepsia are limited. A meta-analysis (57) found that indomethacin, meclofenamate or piroxicam at any dose, and other NSAIDs at high dose but not at low dose, increased the risk of dyspepsia threefold. However, there is evidence (58) that ASA increases the risk of dyspepsia (OR 1.36) compared with placebo. Of note, GI hemorrhage occurs in $2.47 \%$ of those taking ASA (50 mg to $1500 \mathrm{mg}$ ) compared with $1.42 \%$ of nonusers, representing an OR of 1.68 (59). An OR of 1.59 was reported for those taking doses of ASA below $163 \mathrm{mg} /$ day (59). Unfortunately, there are no studies that provide the incidence rate of dyspepsia when patients initiate ASA therapy. Conventional NSAIDs cause dyspepsia at a rate of $13 \%$ to $36 \%$; the wide range is largely the result of varying study definitions of dyspepsia (60). The COXIBs (currently celecoxib, rofecoxib and valdecoxib) can also cause dyspepsia. For celecoxib, the reported cumulative six-month dyspepsia rate was $16.5 \%$ compared with $19.5 \%$ for traditional NSAIDs (53). For rofecoxib, the cumulative six-month dyspepsia rate was $23.5 \%$ compared with $25.5 \%$ for traditional NSAIDs $(54,61)$. Valdecoxib, which has recently become available, also can cause dyspepsia (62-65). The data on etoricoxib are at this point too preliminary to draw any conclusions (66). If ongoing antiinflammatory or antiplatelet therapy is required, a switch to a COXIB can be considered or a trial of a PPI added.

There are no available clinical trial data surrounding improvement of dyspepsia on switching from a conventional NSAID to a COXIB. Essentially, the prevalence of dyspepsia while taking a COXIB is slightly lower compared with a conventional NSAID in some reports $(53,54)$, and is not different according to other reports $(61,62,64,65)$. This recommendation is based solely on expert opinion; there are no published data available to support that such a switch improves dyspepsia. The difficulty with ASA-associated dyspepsia is that it may be difficult to discontinue the ASA therapy if it is being taken because of a well-established cardiac or neurological risk. Clearly the benefits and risks of ASA therapy need to be discussed with the patient and may vary depending on whether one is dealing with primary or secondary prophylaxis for neurological or cardiac disease.

Currently, there is much interest and uncertainty regarding patients taking both an NSAID (or COXIB) and ASA. This issue became evident in the Celecoxib Long-term Arthritis Safety Study (CLASS) (53), a large clinical trial of celecoxib and two conventional NSAIDs, which evaluated serious GI events. In this study, there was evidence that, in patients taking celecoxib, concurrent therapy with ASA abolished the protection against GI complications that was provided by treatment with the COXIB alone. The possible explanation for this is that concurrent use of ASA blocks the COX-1 pathway, thereby negating protection against gastroduodenal injury provided by the COXIB (67). Further studies are required to clarify the possible interactions between ASA and COXIBs. Cotherapy of a COXIB with a PPI or misoprostol may be appropriate but there are no studies that have specifically addressed this.

\section{Interaction between NSAIDs and $\mathrm{H}$ pylori}

There now is evidence for synergy between concurrent conventional NSAID treatment and $H$ pylori infection in causing ulcers (68-71). The interaction is stronger for duodenal than gastric ulcers (68). There is evidence from one Hong Kong study (71) that, for selected patients diagnosed with an ulcer (the study was not directly applicable to patients with UD symptoms) who were taking ASA, eradication of $\mathrm{H}$ pylori was as effective in preventing recurrent ulcers as PPI cotherapy. This is in contrast to results using conventional NSAIDs, which are still associated with recurrent ulcers (19\%) when used after cure of $H$ pylori infection. However, a second study (71) from Hong Kong did not find the same rate of protection in ASA-associated ulcers although, in that study, most bleeding ulcers occurred in $\mathrm{H}$ pylori-positive patients not cured of their infection, or patients taking concurrent NSAID therapy. Studies are needed in North America to clarify these intriguing findings. These considerations support the practice of NSAID primary or secondary prophylaxis, with a PPI or misoprostol, for preventing peptic ulcer complications according to a patient stratification scheme based on the presence of risk factors (age over 65 years, previous peptic ulcer bleed, corticosteroid use, concomitant use of anticoagulation therapy, frailty). Patients on both an NSAID and ASA may be at an even greater risk although there are limited data for this specific situation (72). Here it is important to emphasize that most of the above data focus on patients with known ulcer complications. This population differs from the primary care patient population with uninvestigated symptoms, which is inclusive of this subgroup, and is the subject of the current paper. It therefore requires consideration when implementing any management approach because a decrease in ulcer risk is clinically important and many, but not all, ulcer cases are associated with dyspepsia (73-78).

Given the interactions between NSAIDS and $H$ pylori, the recommendation in patients who are starting, or have recently (under six months) started, an extended course of continuous therapy with conventional NSAIDs or ASA, is to test for $H$ pylori and subsequently confirm eradication. There are no data on ulcer and dyspepsia incidence in $H$ pyloripositive patients taking COXIBs. For rofecoxib, data from the Vioxx Gastrointestinal Outcomes Research (VIGOR) study (76) were analyzed according to $H$ pylori status and no interaction was found between $H$ pylori infection and rofecoxib therapy in causing serious GI events. Ulcers were, however, more common in $\mathrm{H}$ pylori-positive patients. For celecoxib, no data stratified by $\mathrm{H}$ pylori status are available. Checking for cure of the infection is important because a decreased risk of ulcer and its complications will not be observed if the infection persists. Testing is strongly recommended if patients have a history of previous ulcers, ulcer bleeding, or are diagnosed with a gastric or duodenal ulcer while on ASA, a conventional NSAID or a COXIB. However, while the risk is decreased by $H$ pylori eradication, it is not abolished completely. Although results from the Hong Kong studies need further confirmation, the data suggest that patients taking ASA will not need gastric cytoprotection if they are H pylorinegative. In contrast, patients on conventional NSAIDs still 
need prophylaxis despite being $H$ pylori-negative because the risk of ulcer remains high. There are no data available to guide management in patients taking COXIBs who are $\mathrm{H}$ pylori-negative after eradication therapy.

Testing is not routinely recommended in long-term (over one year) NSAID or ASA users who have not experienced dyspepsia or ulcers because the risk of ulcer bleeding complications is low in patients who have not had a bleed within their first year of use $(68,70)$. Caution is warranted if an NSAID is prescribed to a patient already taking ASA (or vice versa) because the second medication may increase the ulcer risk $(77,78)$. More data are needed on the interaction between ASA and either conventional NSAIDs or COXIBs to provide clarification in this area.

\section{Recommendations}

4. Conventional NSAIDs or COXIBs can be a cause of dyspepsia. Preferably the drug should be discontinued to determine whether the dyspepsia resolves.

$\begin{array}{ll}\begin{array}{l}\text { Voting on recommendation } \\ \text { (level/vote) }\end{array} & \mathrm{A} / 12 \\ \begin{array}{l}\text { Level of evidence } \\ \text { Classification of recommendation }\end{array} & \text { C }\end{array}$

5. If stopping the NSAID or COXIB is not possible, consider switching to a different NSAID or COXIB.

\begin{tabular}{ll} 
Voting on recommendation & $\mathrm{A} / 4$ \\
\multicolumn{1}{c|}{ (level/vote) } & $\mathrm{B} / 8$ \\
& $\mathrm{C}$ to E/0 \\
Level of evidence & $\mathrm{II}-3$ \\
Classification of recommendation & $\mathrm{C}$
\end{tabular}

6. If the NSAID or COXIB cannot be stopped, cotherapy with a PPI, misoprostol or high-dose $\mathrm{H}_{2} \mathrm{RA}$ may be considered, although the evidence is for ulcer prophylaxis and not dyspepsia.

$\begin{array}{ll}\begin{array}{ll}\text { Voting on recommendation } \\ \text { (level/vote) }\end{array} & \mathrm{A} / 9 \\ & \mathrm{~B} / 3 \\ \text { Level of evidence } & \mathrm{C} \text { (NS E/0 } \\ & \text { II-2 (COXIB) } \\ \text { Classification of recommendation } & \mathrm{C}\end{array}$

7. If the ASA cannot be stopped, cotherapy with a PPI should be considered.

\begin{tabular}{ll} 
Voting on recommendation & $\mathrm{A} / 2$ \\
\multicolumn{1}{c}{ (level/vote) } & $\mathrm{B} / 10$ \\
& $\mathrm{C}$ to E/0 \\
Level of evidence & $\mathrm{I}$ \\
Classification of recommendation & $\mathrm{B}$
\end{tabular}

8. Testing for H pylori infection is strongly recommended, and proof of eradication advised, if patients have a history of previous ulcers, ulcer bleeding, or are diagnosed with a gastric or duodenal ulcer while on ASA, a conventional NSAID or a selective COXIB.

$\begin{array}{ll}\begin{array}{l}\text { Voting on recommendation } \\ \text { (level/vote) }\end{array} & \text { A/11 } \\ & \text { B/1 } \\ & \text { C to E/0 } \\ \text { Level of evidence } & \text { II-2 (ASA) } \\ & \text { II-3 (NSAID) } \\ \text { Classification of recommendation } & \text { C }\end{array}$

\section{GERD AND HEARTBURN SYMPTOMS}

Initial patient management - further evidence

There are only limited direct data on the comparison of different empirical therapies in uninvestigated patients with reflux symptoms in a primary care environment. A recent meta-analysis (79) of primary care patients with dominant heartburn has shown that the benefit of PPI over $\mathrm{H}_{2} \mathrm{RA}$ therapy was larger for nonendoscoped compared with investigated patients. Due to the paucity of data, recommendations for the management of heartburn-dominant UD are made by extrapolation from the combined healing and symptom resolution results of studies in patients with erosive esophagitis or nonerosive reflux disease (NERD, also referred to as endoscopy-negative reflux disease).

There are conclusive data from acute and long-term studies (80-84) that PPIs provide significantly better healing and symptom relief than $\mathrm{H}_{2}$ RAs (or cisapride) for erosive esophagitis. Similarly, standard-dose PPI is also more effective than low-dose PPI (85-87). Therefore, treatment with a PPI is listed as the first choice. Because there is evidence that a greater proportion of patients will respond to acid suppressive therapy after eight weeks compared with four weeks, it is reasonable to re-evaluate patients after four to eight weeks of initial therapy $(80,83,86)$. The decision whether to initiate therapy with a PPI or $\mathrm{H}_{2} \mathrm{RA}$ should be made after a careful discussion with the patient. However, if an $\mathrm{H}_{2} \mathrm{RA}$ is chosen and the response is inadequate after four to eight weeks, the patient should be switched to a PPI. With respect to heartburn-dominant UD, the superiority of PPIs was documented in a meta-analysis (79) of empirical therapy for GERD, and this analysis also suggested that low-dose PPIs are less effective than standard-dose PPIs for empirical therapy. There are data showing small differences between PPIs with respect to healing, symptom relief and maintenance of remission in patients with erosive esophagitis, but the implications of these findings have yet to be established for symptom management in the larger population of patients with heartburn-dominant UD (87-89).

The recently completed CADET Heartburn-Dominant (CADET-HR) study (83) compared initial therapy with a PPI or $\mathrm{H}_{2} \mathrm{RA}$ followed by on-demand treatment with a PPI or $\mathrm{H}_{2} \mathrm{RA}$ on relapse of symptoms. The results from this study support that a PPI provides better symptom relief than an $\mathrm{H}_{2} \mathrm{RA}$. After four to eight weeks of treatment, relief of heartburn was $55 \%$ for those started on a PPI compared with $27 \%$ for those started on an $\mathrm{H}_{2} \mathrm{RA}$. Of patients started with an $\mathrm{H}_{2} \mathrm{RA}, 47 \%$ needed to be stepped up to a PPI due to inadequate symptom relief. Comparatively, 26\% of those starting with a standarddose PPI needed to be stepped up to higher dose PPI treatment.

For patients with erosive esophagitis, symptom relief at four weeks in response to treatment with a PPI was associated with healing of esophagitis in approximately $80 \%$ of patients (80). There are Canadian data in uninvestigated 


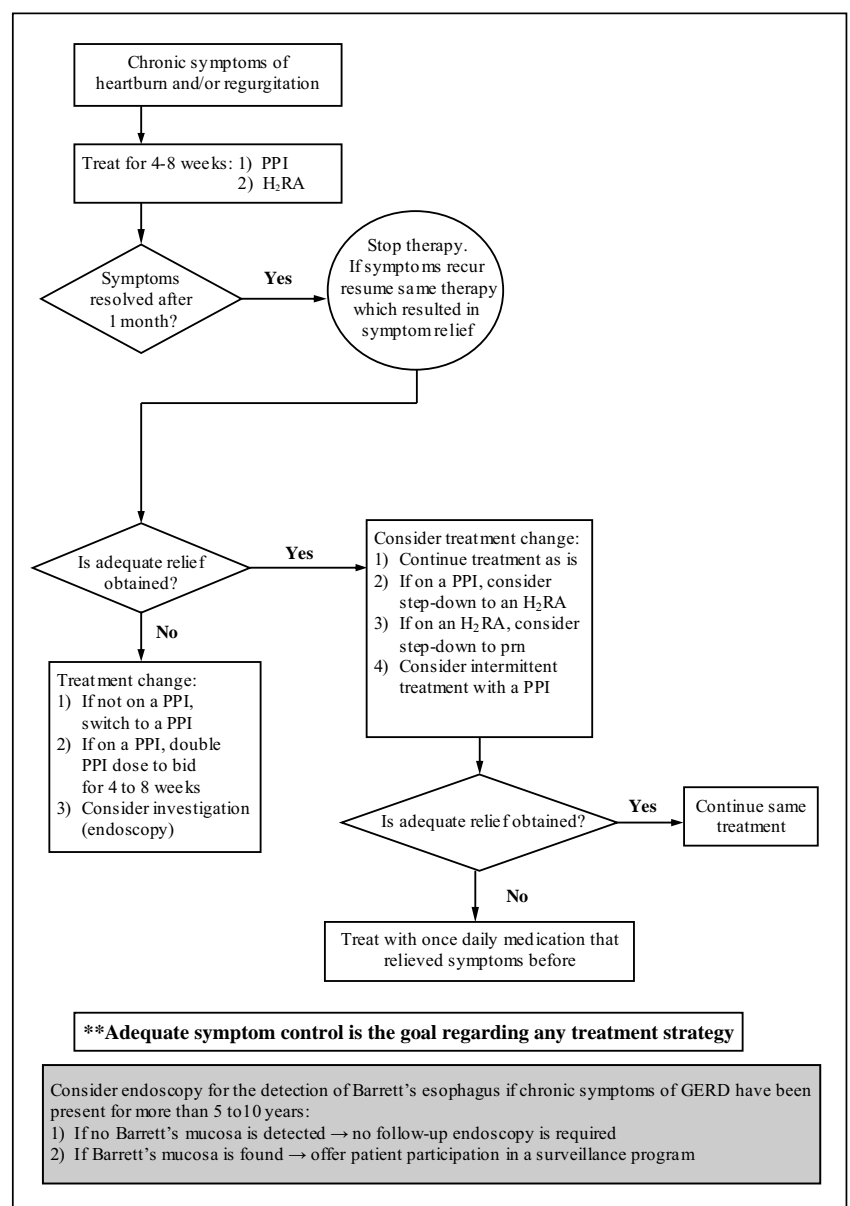

Figure 3) Reflux mini-management scheme. bid Twice daily; GERD Gastroesophageal reflux disease; $\mathrm{H}_{2} \mathrm{RA} \mathrm{H}_{2}$-receptor antagonist; prn As needed; PPI Proton pump inhibitor. Adapted from reference 1

patients with heartburn-dominant or -nondominant dyspepsia that show that a longer duration of treatment improves the response rate. Data from the Canadian Confirmatory Acid Suppression Test (CAST) study (90) showed a significant increment in symptom resolution if treatment with esomeprazole $40 \mathrm{mg}$ once a day was extended from one to four and eight weeks in patients with heartburndominant UD. Thus, the response to initial therapy with a PPI should be evaluated after four to eight weeks of treatment although, in cases where symptoms continue to be unacceptable after four weeks, the physician may choose to review the patient sooner.

The role of endoscopy in dyspepsia patients with longstanding dominant heartburn

In large cohorts of patients in managed care populations, approximately $2 \%$ to $3 \%$ have chronic acid-related disorders (91-93). If a patient is unable to discontinue acid suppressive therapy or has been on acid suppressive therapy for five to 10 years, he or she should be considered for referral for endoscopy if this has not been performed previously. Because there is some evidence that patients have a fear of serious underlying disease (eg, cancer), a normal endoscopy can provide important reassurance to the patient and physician $(94,95)$. A discussion between the patient and physician should include the fact that the risk of serious disease is low and this may help in the decision around the request for and timing of an endoscopy. In patients with long-standing heartburn, the main indication for endoscopy is to exclude complications of esophagitis such as stricture, BE or dysplasia (16).

\section{Recommendation}

Please refer to "BE and esophageal cancer-Recommendation 1"

The patient with symptoms of heartburn and acid regurgitation for five to 10 years who has a normal endoscopy without evidence of $B E$ requires no further follow-up endoscopy unless symptoms change or alarm features develop (96-99). There are no data to indicate that younger patients with a normal endoscopy should have a repeat endoscopy later in life. This recommendation assumes that patients receive optimal acid suppressive therapy for control of their symptoms, defined as treatment that leads to complete or near complete control of symptoms.

\section{Long-term management options for patients with dominant heartburn}

Medical options for long-term therapy in patients with recurrent symptoms include continuous, intermittent or on-demand use of drugs (Figure 3). Long-term therapy with PPIs and $\mathrm{H}_{2} \mathrm{RAs}$ has been demonstrated to be effective and safe (100-106). If PPIs are used initially, then consideration may be given to subsequently trying an $\mathrm{H}_{2} \mathrm{RA}$, although data to support such an approach are limited $(107,108)$. There is evidence that a small proportion of patients can tolerate stepping down but, in the majority of patients, the data show that step-down treatment should not be considered because it leads to worsening of symptoms $(107,108)$. Step-down treatment should not be attempted if the patient remains symptomatic on PPI therapy.

Patients with reflux esophagitis or NERD have a reflux symptom relapse rate of over $80 \%$ after therapy is stopped. Relapse usually requires medication, either continuously or intermittently, for control. It is reasonable to attempt withdrawal of regular therapy for GERD because a small proportion (less than 20\%) of these patients does not need any pharmacological intervention when assessed at six months to one year (107-110). In the CADET-HR study (83), $75 \%$ of these patients relapsed within eight to nine days after first becoming symptom-free and stopping their medication. Thus, the majority of patients will require some form of maintenance therapy.

On-demand therapy, for which patients only take medication during periods when they are experiencing symptoms, is attractive because it leads to decreased use of medication and, hence, drug-related costs. However, data are only available for patients with NERD and not UD (111-116). Alternatively, intermittent dosing (a daily two- to four-week course taken when symptoms recur) is a consideration, but this has only been studied in duodenal ulcer patients before the era of $\mathrm{H}$ pylori infection $(110,116)$.

Antireflux surgery as a long-term management approach is an option for patients who require ongoing medication to control their symptoms or in those who have ongoing symptoms despite medical therapy $(37,117)$. Indications for surgery are changing but a 1999 multivariate analysis (118) concluded that the patients who benefitted the most from an antireflux procedure were those whose symptoms were already controlled on medical therapy. In that study, the best predictors, in order of success, were: $24 \mathrm{~h}$ abnormal $\mathrm{pH}$ profile, heartburn as the dominant symptom and response to medical therapy. In 
Canada in 1996, the rate of antireflux surgical therapy was 11.4 (7.5 abdominal, 0.9 thoracic, 3.0 laparoscopic) per 100,000 population, with a $5.5 \%$ average increase in the use of laparoscopic procedures between 1992 and 1996 (119). Few head-to-head comparisons (120-126) of open versus laparoscopic antireflux procedures have been reported. Functional outcomes, up to two years, appear comparable between the two procedures; however, there is no long-term outcome comparison available. Lundell et al (127) reported their five-year follow-up of a randomly assigned clinical study comparing open antireflux surgery with continuous omeprazole therapy. Overall quality of life did not differ between the two groups, but the surgical group had more dysphagia and inability to belch than the medical group. During long-term follow-up (mean 10.6 years), more than $40 \%$ of operated patients required acid suppression for symptom control (125). In addition, this study reported that laparoscopic fundoplication has a small (less than 1\%) but definite risk of serious complications. CanDys recommends that antireflux surgery only be considered in a small proportion of patients and only after a thorough specialist investigation.

Novel endoscopic techniques have been recently developed that create a barrier to reflux by enhancing lower esophageal sphincter (LES) pressure. These techniques use suturing, injection of a biopolymer or creation of tissue damage using a high radio frequency stimulator at the gastroesophageal junction. There are no head-to-head comparative studies of current treatment alternatives; data (128-130) are short-term with suboptimal selection of outcomes. None of these treatment modalities can currently be recommended in routine practice.

\section{Recommendations}

9. Patients with frequently recurring symptoms of dominant heartburn and/or regurgitation should be treated with the same treatment that led to adequate control during initial treatment.

\begin{tabular}{|c|c|}
\hline $\begin{array}{l}\text { Voting on recommendation } \\
\text { (level/vote) }\end{array}$ & $\begin{array}{l}\mathrm{A} / 11 \\
\mathrm{~B} / 1 \\
\mathrm{C} \text { to } \mathrm{E} / 0\end{array}$ \\
\hline $\begin{array}{l}\text { Level of evidence } \\
\text { Classification of recommendation }\end{array}$ & I \\
\hline
\end{tabular}

10. In patients with dominant symptoms of heartburn and/or regurgitation, maintenance therapy with a PPI is more effective for symptom control than with an $\mathrm{H}_{2} \mathrm{RA}$, for both acute and long-term therapy.

$\begin{array}{ll}\begin{array}{l}\text { Voting on recommendation } \\ \text { (level/vote) }\end{array} & \mathrm{A} / 12 \\ \text { Level of evidence } & \mathrm{B} \text { to } \mathrm{E} / 0 \\ \text { Classification of recommendation } & \mathrm{I}\end{array}$

11. Antireflux surgery should only be considered for those who are unable or unwilling to take long-term acid suppressive medication.

$\begin{array}{cl}\text { Voting on recommendation } & \mathrm{A} / 10 \\ \text { (level/vote) } & \mathrm{B} / 2 \\ & \mathrm{C} \text { to } \mathrm{E} / 0\end{array}$

\section{Level of evidence \\ I \\ Classification of recommendation A}

Management of patients with long-standing dominant heartburn and $H$ pylori infection

In Canada, the overall prevalence of $H$ pylori infection is $25 \%$ to $30 \%$ (6). Age is an important risk factor. Most studies, including CADET-PE (6,131-134), have shown a lower prevalence of $H$ pylori infection in patients with esophagitis compared with those without. H pylori-infected patients may have gastritis in the body of the stomach which may decrease gastric acid output and thereby lower the potential for acid reflux and resultant esophagitis. There has been controversy over whether cure of $H$ pylori infection might provoke or lead to worsening of GERD. Most of the evidence (135-140) shows that this is not the case.

Patients with GERD who require long-term acid suppression, especially with a PPI, and who are infected with $H$ pylori, have a worsening of gastritis in the body of the stomach (141). This deterioration of histological gastritis is not seen in $H$ pylori-negative patients taking PPIs or in those in whom $H$ pylori infection has been cured (142-147). Several randomly assigned controlled trials $(148,149)$, however, have shown that cure of the $H$ pylori infection leads to regression of the body gastritis. To date, there is no evidence that the deterioration in gastritis has serious long-term consequences (such as gastric cancer). Hence, it is the CanDys recommendation that a routine 'test for H pylori and treat if positive' strategy is not necessary in patients requiring long-term PPI therapy (over one year).

\section{Recommendation}

12. Routine testing for $H$ pylori is not required for patients on long-term PPI therapy. However, it is reasonable to do so on a case-by-case basis.

$\begin{array}{ll}\begin{array}{ll}\text { Voting on recommendation } \\ \text { (level/vote) }\end{array} & \mathrm{A} / 2 \\ & \mathrm{~B} / 6 \\ \mathrm{C} / 1 \\ \mathrm{D} / 1 \\ & \mathrm{E} / 0 \\ & \mathrm{II}-3 \\ \text { Level of evidence } & \mathrm{C}\end{array}$

Management of patients with nonheartburn-dominant dyspepsia and $\mathrm{H}$ pylori infection

The CMT recommendation for patients with dyspepsia who are not using NSAIDs or ASA and who do not have dominant symptoms of heartburn is a noninvasive test for $\mathrm{H}$ pylori, and treatment if the test is positive. The CADET $H$ pylori (CADET-Hp) study (3) compared a one-week PPI-based eradication regimen with placebo (empirical twice-a-day PPI) treatment given for one week, to determine whether $\mathrm{H}$ pylori treatment does lead to long-term improvement in dyspepsia symptoms. This study of 296 patients showed that there was symptomatic improvement at 12 months in $50 \%$ of patients, in whom $H$ pylori infection was cured, compared with $36 \%$ of controls with persistent infection ( $\mathrm{P}=0.02)$. The number needed to treat to achieve one long-term success was seven patients. It is important to note that while all patients presented with a primary complaint of epigastric pain, a proportion (30\%) of the patients also had dominant heartburn and/or regurgitation. 
A post hoc subgroup analysis suggested that, in a small population of patients, heartburn symptoms will improve after $H$ pylori eradication. The benefit of curing $H$ pylori has been supported in other studies as well (150-153). The benefits of the test-and-treat approach are probably derived mainly from treatment of underlying ulcer disease and possibly improving a small proportion of functional dyspepsia patients (150-153). The lifetime risk in an $\mathrm{H}$ pylori-infected individual to develop ulcers is $5 \%$ to $15 \%(154,155)$. It is important to note that, despite successful treatment of the infection, a substantial proportion of patients (at least 50\%) will require ongoing treatment for dyspepsia symptoms. In such cases, three options exist: retest for $H$ pylori infection using a urea breath test (UBT) to ensure the infection has been cured; institute empirical therapy in accordance with the CMT recommendations; or perform endoscopy if clinically indicated, at which time biopsies for $H$ pylori infection should be taken.

\section{Recommendation}

13. In patients with dyspepsia who do not have alarm symptoms or symptoms of dominant heartburn or acid regurgitation, and are not using NSAIDs or ASA, a test for $\mathrm{H}$ pylori should be ordered and the patient treated if positive.

\begin{tabular}{|c|c|}
\hline $\begin{array}{l}\text { Voting on recommendation } \\
\text { (level/vote) }\end{array}$ & $\begin{array}{l}\mathrm{A} / 10 \\
\mathrm{~B} / 2 \\
\mathrm{C} \text { to } \mathrm{E} / 0\end{array}$ \\
\hline Level of evidence & I \\
\hline
\end{tabular}

\section{TREATMENT OF H PYLORI INFECTION}

Treatment, as recommended in the CMT (1), consists of triple therapy with a PPI twice a day, clarithromycin $500 \mathrm{mg}$ twice a day and either amoxicillin $1000 \mathrm{mg}$ twice a day or metronidazole $500 \mathrm{mg}$ twice a day. Recently, it has been recommended that PPI-clarithromycin-amoxicillin be used firstline because that combination is unaffected by resistance to metronidazole. Although there are limited data, the prevalence of metronidazole resistance in Canada is estimated to be approximately $20 \%(156-160)$. First-line use with a metronidazole-containing regimen is a reasonable alternative for patients with a penicillin allergy. Regarding the duration of eradication treatment, the recommendation continues to be seven to 10 days for the first treatment $(161,162)$. Recent data $(156,163,164)$ suggest that bismuth-based quadruple therapy may be as effective as PPI-based triple therapy and, therefore, could be considered as an alternative first-line therapy. However, this therapy is more complicated and involves taking 18 tablets a day. All PPIs available in Canada (esomeprazole, lansoprazole, omeprazole, pantoprazole and rabeprazole) have similar efficacy in curing $\mathrm{H}$ pylori with combinations of clarithromycin-metronidazole or clarithromycinamoxicillin (165-167). Eradication failure is a concern because PPI-clarithromycin-amoxicillin or PPI-clarithromycinmetronidazole combinations are not successful in 15\% to $25 \%$ of cases (168). Quadruple therapy (PPI twice a day, bismuth subsalicylate two tablets four times a day, tetracycline $500 \mathrm{mg}$ four times a day and metronidazole $250 \mathrm{mg}$ to $500 \mathrm{mg}$ four times a day) for 10 to 14 days is the preferred therapy for H pylori treatment failures $(156,164,168)$.

\section{Recommendations}

14. Patients who are H pylori-positive should be treated with a combination of PPI, clarithromycin and amoxicillin for seven to 10 days. PPI-clarithromycin-metronidazole can be used if the patient is allergic to penicillin.

$\begin{array}{ll}\begin{array}{ll}\text { Voting on recommendation } \\ \text { (level/vote) }\end{array} & \mathrm{A} / 12 \\ \begin{array}{l}\text { Level of evidence } \\ \text { Classification of recommendation }\end{array} & \mathrm{A}\end{array}$

15. Quadruple therapy (PPI plus bismuth-metronidazoletetracycline) for 10 to 14 days is an acceptable first-line alternative.

$\begin{array}{ll}\begin{array}{l}\text { Voting on recommendation } \\ \text { (level/vote) }\end{array} & \mathrm{A} / 12 \\ \text { Level of evidence } & \mathrm{B} \text { to E/0 } \\ \text { Classification of recommendation } & \mathrm{I}\end{array}$

Diagnostic tests for $\mathrm{H}$ pylori

The most frequently used diagnostic test for $\mathrm{H}$ pylori infection is serology. The UBT is recommended because it has a higher positive predictive value (predicting the true presence of infection) and negative predictive value (predicting the true absence of infection) compared with serology, over a broad infection prevalence range $(169,170)$. However, the UBT is not readily available across Canada and access may be limited due to lack of reimbursement. For serology, the negative predictive value is high (over 90\%) while the positive predictive value is reduced to $70 \%$ to $80 \%$, especially in individuals less than 40 years of age who have a lower (less than 20\%) H pylori prevalence (170). This means that when serology is used, a significant proportion of patients will be treated based on false-positive test results.

The European Helicobacter pylori Study Group has recommended use of the stool antigen test of $\mathrm{H}$ pylori detection (171). This procedure has not been adequately tested and is not available in the primary care setting (or most secondary or tertiary settings) in Canada and, therefore, is not recommended by CanDys.

\section{Testing for $\mathrm{H}$ pylori infection following treatment}

It is not mandatory to routinely test patients following an eradication attempt unless they have ongoing or recurrent symptoms (171). Testing for cure of $H$ pylori should be performed in all patients who have had a bleeding ulcer, and acid suppression therapy should be continued until it is determined that the patient is $H$ pylori-negative, with the caveat that they should discontinue PPIs seven to 14 days before a UBT to minimize the risk of a false-negative study. Serology is not an acceptable follow-up test because antibodies may remain detectable for over 12 months despite successful cure of the infection (170). If UBT is not available, endoscopy with biopsies may be performed to document cure if the endoscopy is clinically indicated. Should the patient continue to be $H$ pylori-positive, retreatment with an alternative eradication therapy is recommended.

In Canada, the success rate of $H$ pylori eradication treatment is high ( $75 \%$ to $85 \%$ ) and, therefore, it is likely that, once treated, patients will become $H$ pylori-negative. Acid suppressive therapy is the treatment of choice for ongoing symptoms, and it is reasonable to start this treatment as soon as the patient 
returns for management of symptoms rather than awaiting the results of further $\mathrm{H}$ pylori testing.

It is recognized that PPIs suppress $H$ pylori, although cure of the infection with PPI monotherapy is very rare $(172,173)$. Up to $20 \%$ of patients may test falsely negative for the infection if PPIs are used at the time that a UBT is performed (174-180). The recommendation is to stop PPIs for 14 days before the UBT $(181,182)$. In practice, this may be difficult because some patients will have worsening of symptoms during this interval. Often this can be bridged with the use of antacids. For $\mathrm{H}_{2} \mathrm{RAs}$, the recommendation is to stop for seven days before testing because they too can have an effect on $H$ pylori $(183,184)$. In practice, it may be reasonable to use two weeks as a guideline for all such medications. Antimicrobials and bismuth compounds must be discontinued for four weeks before a UBT to avoid false-negative test results.

\section{Recommendations}

16. Patients who have ongoing or recurrent dyspepsia symptoms following $H$ pylori treatment should be tested by UBT (not serology) or undergo endoscopy with biopsies to determine whether $H$ pylori is present.

$\begin{array}{ll}\text { Voting on recommendation } & \mathrm{A} / 1 \\ \text { (level/vote) } & \mathrm{B} / 1 \\ & \mathrm{C} \text { to } \\ \text { Level of evidence } & \mathrm{I} \\ \text { Classification of recommendation } & \mathrm{A}\end{array}$

17. If the patient continues to test positive (not serology) for $H$ pylori infection, retreatment with an alternative regimen should be given, for which quadruple therapy is the treatment of choice.

$\begin{array}{ll}\text { Voting on recommendation } & \mathrm{A} / 11 \\ & \mathrm{~B} / 1 \\ & \mathrm{C} \text { to E/0 } \\ \text { Level of evidence } & \mathrm{III} \\ \text { Classification of recommendation } & \mathrm{C}\end{array}$

18. If the patient retests negative, he or she should be treated as an $\mathrm{H}$ pylori-negative dyspepsia patient with acid suppression as defined in the CMT.

$\begin{array}{ll}\text { Voting on recommendation } & \mathrm{A} / 3 \\ \text { (level/vote) } & \mathrm{B} / 9 \\ & \mathrm{C} \text { to E/0 } \\ \text { Level of evidence } & \mathrm{III} \\ \text { Classification of recommendation } & \mathrm{C}\end{array}$

\section{Management of $\mathrm{H}$ pylori-negative patients}

The CMT recommends treatment for four to eight weeks with a PPI or $\mathrm{H}_{2} \mathrm{RA}$ for $\mathrm{H}$ pylori-negative patients who are not using NSAIDs or ASA, and whose symptoms do not suggest GERD. There is evidence (185-191) that, for this patient group, a PPI provides superior efficacy compared with an $\mathrm{H}_{2} \mathrm{RA}$ or a prokinetic agent. As well, a greater proportion of patients will respond after eight weeks of treatment, compared with after four weeks (85).

Few long-term efficacy studies have been published in $H$ pylori-negative dyspepsia patients; however, available data indicate that PPIs provide better efficacy compared with $\mathrm{H}_{2}$ RAs. The CADET H pylori-negative (CADET-HN) study
(188) compared a PPI, an $\mathrm{H}_{2} \mathrm{RA}$, a prokinetic agent and placebo in uninvestigated $\mathrm{H}$ pylori-negative dyspepsia patients. After four weeks of continuous treatment, those given a PPI had a superior response $(51 \%)$ relative to that of the other three treatments $(36 \%, 30 \%$ and $23 \%$, respectively; $\mathrm{P}=0.01)$. This study had a five-month follow-up phase during which patients continued the same drug in an on-demand fashion. Response rates in the on-demand phase, during which patients on average took medication every other day, were not as high as during the acute treatment phase. The proportion of patients who were responders at both four weeks and six months were: omeprazole $31 \%$, ranitidine $21 \%$, cisapride $13 \%$ and placebo $14 \%(\mathrm{P}<0.05$, omeprazole versus cisapride or placebo $)$.

The CMT was published in June 2000 when the prokinetic agent cisapride was still available. This agent has since been withdrawn from most markets due to rare but possibly lifethreatening cardiac arrhythmias. Cisapride is currently available only under special authorization for patients with severe gastroparesis; it should not be used for the treatment of dyspepsia. For the two other available prokinetic agents (domperidone and metoclopramide), there is very limited evidence $(190,191)$ regarding efficacy in dyspepsia. However, in clinical practice, patients who do not respond to high-dose acid suppression therapy are often tried on prokinetic agents despite limited published clinical data to support such an approach.

\section{Recommendations}

19. Patients with $H$ pylori-negative dyspepsia should be treated with a course (four to eight weeks) of acid suppressive therapy as recommended in the CMT.

$\begin{array}{ll}\begin{array}{l}\text { Voting on recommendation } \\ \text { (level/vote) }\end{array} & \mathrm{A} / 12 \\ & \mathrm{~B} \text { to E/0 } \\ \begin{array}{l}\text { Level of evidence } \\ \text { Classification of recommendation }\end{array} & \mathrm{I}\end{array}$

20. In patients with $H$ pylori-negative dyspepsia, PPIs are more effective than $\mathrm{H}_{2} \mathrm{RAs}$ in symptom control, for both acute and long-term therapy.

$\begin{array}{cl}\begin{array}{l}\text { Voting on recommendation } \\ \text { (level/vote) }\end{array} & \mathrm{A} / 12 \\ \mathrm{~B} \text { to } \mathrm{E} / 0\end{array}$

Level of evidence III

Classification of recommendation C

\section{Management of nonresponders}

In the case of a patient (either heartburn-dominant or nonheartburn-dominant $H$ pylori-negative) with only partial or no symptom response to a course of standard-dose acid suppression, the CMT recommends to increase the degree of acid suppression to a PPI if an $\mathrm{H}_{2} \mathrm{RA}$ was given, increase the dose of a PPI to twice a day, or treat for a further four to eight weeks with the same dose. There are no clinical trial data for the last approach. If a patient fails to improve with a course of double-dose PPI for four to eight weeks, it is unlikely that the symptoms are acid-sensitive, and the PPI should be discontinued, symptoms reviewed and the patient investigated further (eg, endoscopy).

\section{Recommendation}

21. If, after a course of initial standard-dose acid suppression, a patient does not respond to a further 
four to eight weeks of high-dose PPI, then further investigations, such as endoscopy, may be required.

$\begin{array}{ll}\begin{array}{l}\text { Voting on recommendation } \\ \text { (level/vote) }\end{array} & \mathrm{A} / 12 \\ \begin{array}{l}\text { Level of evidence } \\ \text { Classification of recommendation }\end{array} & \mathrm{C}\end{array}$

\section{Management of partial responders}

It is uncertain how to manage patients with a partial symptomatic response. There is no set definition for a partial response; however, it can typically be defined by one or more of the following: incomplete symptom control, return clinic visits or unwillingness to continue prescribed therapy. Medication compliance may play a role because there is a theoretical advantage to the administration of PPI once a day (in the case of a single standard dose) given $30 \mathrm{~min}$ to $60 \mathrm{~min}$ before breakfast, the time when acid pumps are most readily blocked (192-195). It is rational to consider a switch in medication or increase in dose of the treatment for another four- to eight-week period (if on an $\mathrm{H}_{2} \mathrm{RA}$, switch to a PPI and if on a PPI, give a higher split dose), despite lack of supportive data for this approach.

\section{Recommendation}

22. If a patient has not responded, or has only partially responded, to a four- to eight-week treatment with an $\mathrm{H}_{2} \mathrm{RA}$ or a PPI, consider switching to a PPI if the patient was on an $\mathrm{H}_{2} \mathrm{RA}$, or if on a PPI, doubling the dose of the PPI for another four to eight weeks.

$\begin{array}{cl}\text { Voting on recommendation } & \mathrm{A} / 11 \\ \text { (level/vote) } & \mathrm{B} / 1 \\ & \mathrm{C} \text { to E/0 }\end{array}$

$\begin{array}{ll}\text { Level of evidence } & \text { III } \\ \text { Classification of recommendation } & \text { C }\end{array}$

\section{OTC medications}

Several epidemiological studies (196) have shown that a high percentage of people with dyspepsia have tried OTC products as an initial step in management of their symptoms. OTC drugs include antacids, alginate-based products, $\mathrm{H}_{2}$ RAs, bismuth products and herbal products. Published studies of these agents include few randomly assigned controlled trials and relate to a broad spectrum of patient populations, primarily functional dyspepsia or heartburn-predominant dyspepsia patient populations.

Antacid products have been shown to provide symptomatic relief of heartburn in some but not all studies (197), but have no effect on healing of erosive esophagitis. They may provide more prompt symptom relief than OTC doses of $\mathrm{H}_{2}$ RAs (198). Thus, the evidence suggests that antacids should be used for unpredictable episodes of heartburn and for symptomatic 'breakthrough' episodes of heartburn. Several studies $(199,200)$ suggest that the benefit of antacids probably stems from their ability to provide intraesophageal neutralization of acid rather than neutralization of acid present in the stomach. $\mathrm{H}_{2} \mathrm{RAs}$ in OTC formulations containing onehalf of the prescription strength product per unit dose (eg, ranitidine $75 \mathrm{mg}$, famotidine $10 \mathrm{mg}$ ) do lower gastric acid secretion (201,202). Randomly assigned controlled trials (203-206) of these agents (low-dose OTC cimetidine, ranitidine, famotidine) have shown that these products produce significantly greater relief or prevention of postprandial reflux symptoms than placebo. These drugs are well-tolerated with few side effects reported. The ideal use of the OTC $\mathrm{H}_{2} \mathrm{RAs}$ is to administer the dose $1 \mathrm{~h}$ to $2 \mathrm{~h}$ before episodic and/or predictable occurrences of heartburn, such as before meals (27).

Alginate-based products (Gaviscon, GlaxoSmithKline, USA) are approved for heartburn relief only. Both in vitro and in vivo studies (207) have shown that these agents produce their benefit by forming a 'raft' or foamy physical barrier that may prevent gastroesophageal reflux. Alginate products must be taken approximately one-half hour after meals to produce this effect and subsequent benefit; taking these products before or during meals destroys the ability of the alginate to form an effective raft to reside on the gastric contents. Clinical trials (204) demonstrate that various alginate formulations produce heartburn relief significantly better than placebo; comparisons with antacids have produced varying results of benefit of one over the other.

Many herbal product manufacturers and distributors claim efficacy for their products in dyspepsia; however, there are few well-designed randomly assigned controlled trials (208) that substantiate this, and most of these studies are in patients with functional dyspepsia. Only studies of products containing a combination of peppermint and caraway oils reported benefit over placebo, but the evidence is insufficient to support any recommendations.

In all instances when OTC medications do not provide adequate symptom relief for the patient, or symptoms occur frequently, patients should be advised to consult their family practitioner for further discussion and assessment of dyspepsia symptoms.

\section{Recommendations}

23. For infrequent or unpredictable episodes of dyspepsia, OTC medication can provide relief.

$\begin{array}{ll}\text { Voting on recommendation } & \mathrm{A} / 7 \\ \text { (level/vote) } & \mathrm{B} / 5 \\ & \mathrm{C} \text { to E/0 } \\ \text { Level of evidence } & \mathrm{I} \\ \text { Classification of recommendation } & \mathrm{B}\end{array}$

24. If the requirement for OTC medications is frequent and/or symptoms influence daily living, then a physician should be consulted.

$\begin{array}{ll}\begin{array}{l}\text { Voting on recommendation } \\ \text { (level/vote) }\end{array} & \mathrm{A} / 12 \\ \begin{array}{l}\text { Level of evidence } \\ \text { Classification of recommendation }\end{array} & \mathrm{C}\end{array}$

\section{Pregnancy and lactation}

Dyspepsia in pregnancy is common, with heartburn and acid regurgitation reported by $45 \%$ to $80 \%$ of pregnant women as the most bothersome GI symptoms, especially in the latter half of the pregnancy (2109-210). The high frequency of reflux symptoms likely occurs as a result of increased abdominal pressure due to the growing gravid uterus and a decrease in LES pressure caused by changes in hormonal status $(211,212)$. There is good evidence (213) that abnormal LES pressure 
normalizes soon after delivery. There is obvious concern about the use of medications in pregnancy up to the 14th week during organogenesis when teratogenic risks are greatest and therefore have the most potential to damage the fetus. The Motherisk program (http://www.motherisk.org/) may be consulted, accordingly, for drug-specific or breastfeeding information. Recommendations related to drug use in pregnancy stem from data in animals regarding potential teratogenicity. There are data from randomly assigned and nonrandomly assigned studies and reviews in pregnancy $(214-222)$ but their numbers are small. Antacids should be tried first. An $\mathrm{H}_{2} \mathrm{RA}$ may be prescribed if antacids fail to provide adequate relief. Most of the safety data for for $\mathrm{H}_{2} \mathrm{RAs}$ is for ranitidine. Should $\mathrm{H}_{2} \mathrm{RAs}$ not suffice, a PPI can be considered. For PPIs, most of the data come from small cohort studies in women using omeprazole (214). Other data (223) suggest that there is no evidence of measurable teratogenic risk, increased risk of abortion or risk of low birth weight in humans with the use of $\mathrm{H}_{2} \mathrm{RAs}$ (particularly ranitidine) or PPIs (particularly omeprazole) during pregnancy. It must be noted that there are limited data with regard to these recommendations and, as such, very judicious and careful use of such medications is required. Meta-analysis data (214) of the Motherisk program suggest that omeprazole is safe. However, the Food and Drug Administration has assigned omeprazole a category C (human data lacking; animal studies positive; or not performed) based on animal data, suggesting possible toxicity in embryos using high doses of omeprazole. This in contrast to lansoprazole (Food and Drug Administration category B: human data reassuring [animalpositive]; or animal studies show no risk) where animal data did not show toxicity (224).

For breastfeeding, the recommendation is to initially try antacids, followed by an $\mathrm{H}_{2} \mathrm{RA}$ and then a PPI. For both $\mathrm{H}_{2} \mathrm{RAs}$ and PPIs (data are only available for omeprazole), there is evidence (225) that they are excreted in breastmilk but their levels are low and considered unlikely to be of clinical consequence; PPIs, therefore, probably can be used safely. As with all medications, these drugs should only be used if the symptoms are sufficiently severe to require treatment.

\section{Recommendation}

25. In pregnancy, or when breastfeeding, treatments for dyspepsia symptoms should be used in the following order:

a) Antacids

b) $\mathrm{H}_{2} \mathrm{RAs}$ (most data available for ranitidine) or PPIs (most data available for omeprazole)

\begin{tabular}{ll} 
Voting on recommendation & $\mathrm{A} / 11$ \\
\multicolumn{1}{l}{ (level/vote) } & $\mathrm{B} / 1$ \\
& $\mathrm{C}$ to $\mathrm{E} / \mathrm{O}$ \\
Level of evidence & $\mathrm{II}-2$ \\
Classification of recommendation & $\mathrm{B}$
\end{tabular}

\section{Dyspepsia and psychosocial factors}

Most evidence correlating psychosocial distress with dyspepsia arises from studies $(226,227)$ of investigated, functional (nonulcer) dyspepsia. Patients consulting for dyspepsia are more likely to have experienced psychosocial stress in the preceding six months (228). Socioeconomic challenges, low expectations, depression and less optimism are predictors of poor outcomes in functional dyspepsia (228). Health-related quality of life, measured at one year, is more closely linked to psychological distress than to the severity of dyspepsia (229). Addressing psychological factors can have an important impact on the long-term outcome of related dyspepsia symptoms (227). Although there are no specific data from UD studies, it is reasonable for the physician to determine psychological stressors when a patient presents.

\section{Antidepressants and psychological interventions}

Apart from improving mood, antidepressants have also been used in the treatment of functional GI disorders such as irritable bowel syndrome, noncardiac chest pain and functional (investigated) dyspepsia (230). The limited evidence for UD patients in this area precludes any recommendation. There is emerging evidence on selective serotonin reuptake inhibitor treatment and the apparent risk of peptic ulceration associated with its use; however, the data $(231,232)$ centre on the risk of GI bleeding rather than dyspepsia. There are no treatment data in UD evaluating the effect of psychotherapy or other psychological treatment. It is self-evident that, if mood disturbance presents as a health concern, then it should be discussed with the patient (233).

\section{CONCLUSIONS}

The CMT described in the present paper provides evidencebased recommendations for both the acute and long-term management of UD patients. In addition to recommendations for patients taking ASA or NSAIDs and patients with either heartburn-dominant or -nondominant dyspepsia, recommendations are provided on once-in-a-lifetime endoscopy in patients with long-standing dyspepsia, the age cut-off above which initial investigation is recommended, and the need for the treatment of $H$ pylori infection in patients receiving long-term acid suppressive therapy. Recent clinical data, including primary care-based studies from Canada, have provided grade $\mathrm{A}$, level 1 evidence for many of the treatment recommendations. Future studies should help to optimize the management of dyspepsia in primary care.

ACKNOWLEDGEMENTS: The following people were members of the CanDys Working Group and contributed to this work: Dr William Bartle, University of Toronto, Pharmacy Department, Sunnybrook Health Sciences Centre, Toronto, Ontario; Dr Patricia Blackshaw, Surrey Memorial Hospital, Surrey, British Columbia; Dr Brian Craig, Department of Family Medicine, Dalhousie University, Department of Family Medicine, Atlantic Health Sciences Corporation, Saint John Regional Hospital Facility, Saint John, New Brunswick; Dr Krishnasamy Govender, Department of General Practice, Regina Health District, Regina, Saskatchewan; Dr Bernard Marlow, Department of Family and Community Medicine, University of Toronto, Toronto, Ontario; Dr Richard McCammon, Physician Manager (retired), Salvation Army Grace General Hospital, Winnipeg, Manitoba; and Dr Robert Woodland, Department of Family Practice, Health Care Corporation, St John's, Newfoundland. 


\section{REFERENCES}

1. Veldhuyzen van Zanten SJ, Flook N, Chiba N, et al. An evidencebased approach to the management of uninvestigated dyspepsia in the era of Helicobacter pylori. Canadian Dyspepsia Working Group. CMAJ 2000;162(Suppl 12):S3-23.

2. Talley NJ, Stanghellini V, Heading RC, Koch KL, Malagelada JR, Tytgat GN. Functional gastroduodenal disorders. Gut 1999;45(Suppl 2):II37-42.

3. Chiba N, Van Zanten SJ, Sinclair P, Ferguson RA, Escobedo S, Grace E. Treating Helicobacter pylori infection in primary care patients with uninvestigated dyspepsia: The Canadian adult dyspepsia empiric treatment-Helicobacter pylori positive (CADET$\mathrm{Hp})$ randomised controlled trial. BMJ 2002;324:1012-6.

4. Moayyedi P, Feltbower R, Brown J, et al. Effect of population screening and treatment for Helicobacter pylori on dyspepsia and quality of life in the community: A randomised controlled trial. Leeds HELP Study Group. Lancet 2000;355:1665-9.

5. Wildner-Christensen M, Moller Hansen J, Schaffalitzky De Muckadell OB. Rates of dyspepsia one year after Helicobacter pylori screening and eradication in a Danish population. Gastroenterology 2003;125:372-9.

6. Thomson AB, Barkun AN, Armstrong D, et al. The prevalence of clinically significant endoscopic findings in primary care patients with uninvestigated dyspepsia: The Canadian Adult Dyspepsia Empiric Treatment - Prompt Endoscopy (CADET-PE) study. Aliment Pharmacol Ther 2003;17:1481-91. (Erratum in 2004;20:72).

7. Talley NJ, Weaver AL, Tesmer DL, Zinsmeister AR. Lack of discriminant value of dyspepsia subgroups in patients referred for upper endoscopy. Gastroenterology 1993;105:1378-86.

8. Barkun A, Bardou M, Marshall JK. Nonvariceal Upper GI Bleeding Consensus Conference Group. Consensus recommendations for managing patients with nonvariceal upper gastrointestinal bleeding. Ann Intern Med 2003;139:843-57.

9. The Society for Surgery of the Alimentary Tract (SSAT), American Gastroenterological Association (AGA), American Society for Gastrointestinal Endoscopy (ASGE) Consensus Panel. Management of Barrett's esophagus. J Gastrointest Surg 2000;4:115-6.

10. Sampliner RE. The Practice Parameters Committee of the American College of Gastroenterology. Updated guidelines for the diagnosis, surveillance, and therapy of Barrett's esophagus. Am J Gastroenterol 2002;97:1888-95.

11. Axon AT, Bell GD, Jones RH, Quine MA, McCloy RF. Guidelines on appropriate indications for upper gastrointestinal endoscopy. Working Party of the Joint Committee of the Royal College of Physicians of London, Royal College of Surgeons of England, Royal College of Anaesthetists, Association of Surgeons, the British Society of Gastroenterology, and the Thoracic Society of Great Britain. BMJ 1995;310:853-6.

12. de Wit NJ, Mendive J, Seifert B, Cardin F, Rubin G. Guidelines on the management of $\mathrm{H}$ pylori in primary care: Development of an implementation strategy. Fam Pract 2000;17(Suppl 2):S27-32.

13. Talley NJ, Axon A, Bytzer P, Holtmann G, Lam SK, van Zanten S. Management of uninvestigated and functional dyspepsia: A Working Party report for the World Congresses of Gastroenterology 1998. Aliment Pharmacol Ther 1999;13:1135-48.

14. The British Society of Gastroenterology guidelines on dyspepsia. London: British Society of Gastroenterology, 2002.

$<$ www.bsg.org.uk/pdf_word_docs/dyspepsia.doc> (Version current at February 15, 2005).

15. The Scottish Intercollegiate Guidelines Network (SIGN). Dyspepsia. Edinburgh: Scottish Intercollegiate Guidelines Network, 2003. <http://www.sign.ac.uk/guidelines/fulltext/68/index.html> (Version current at February 15, 2005).

16. Inadomi JM, Sampliner R, Lagergren J, Lieberman D, Fendrick AM, Vakil N. Screening and surveillance for Barrett esophagus in highrisk groups: A cost-utility analysis. Ann Intern Med 2003;138:176-86.

17. Canga C III, Vakil N. Upper GI malignancy, uncomplicated dyspepsia, and the age threshold for early endoscopy. Am J Gastroenterol 2002;97:600-3.

18. Breslin NP, Thomson AB, Bailey RJ, et al. Gastric cancer and other endoscopic diagnoses in patients with benign dyspepsia. Gut 2000;46:93-7.
19. Voutilainen M, Mantynen T, Kunnamo I, Juhola M, Mecklin JP, Farkkila M. Impact of clinical symptoms and referral volume on endoscopy for detecting peptic ulcer and gastric neoplasms. Scand J Gastroenterol 2003;38:109-13.

20. Meineche-Schmidt V, Jorgensen T. Alarm symptoms in patients with dyspepsia: A three-year prospective study from general practice. Scand J Gastroenterol 2002;37:999-1007.

21. Manes G, Balzano A, Marone P, Lioniello M, Mosca S. Appropriateness and diagnostic yield of upper gastrointestinal endoscopy in an open-access endoscopy system: A prospective observational study based on the Maastricht guidelines. Aliment Pharmacol Ther 2002;16:105-10.

22. Falk GW. Barrett's esophagus. Gastroenterology 2002;122:1569-91.

23. Avidan B, Sonnenberg A, Schnell TG, Sontag SJ. There are no reliable symptoms for erosive oesphagitis and Barrett's oesophagus: Endoscopic diagnosis is still essential. Aliment Pharmacol Ther 2002;16:735-42.

24. Avidan B, Sonnenberg A, Schnell TG, Sontag SJ. Hiatal hernia and acid reflux frequency predict presence and length of Barrett's esophagus. Dig Dis Sci 2002;47:256-64.

25. Eckardt VF, Kanzler G, Bernhard G. Life expectancy and cancer risk in patients with Barrett's esophagus: A prospective controlled investigation. Am J Med 2001;111:33-7.

26. Katzka DA, Rustgi AK. Gastroesophageal reflux disease and Barrett's esophagus. Med Clin North Am 2000;84:1137-61.

27. National Cancer Institute of Canada. Canadian Cancer Statistics. Toronto: National Cancer Institute of Canada, 2002.

28. Lagergren J, Bergstrom R, Lindgren A, Nyren O. Symptomatic gastroesophageal reflux as a risk factor for esophageal adenocarcinoma. N Engl J Med 1999;340:825-31.

29. Shaheen N, Ransohoff DF. Gastroesophageal reflux, Barrett's esophagus and esophageal cancer: Scientific review. JAMA 2002;287:1972-81.

30. Avidan B, Sonnenberg A, Schnell TG, Chejfec G, Metz A, Sontag SJ. Hiatal hernia size, Barrett's length, and severity of acid reflux are all risk factors for esophageal adenocarcinoma. Am J Gastroenterol 2002;97:1930-6.

31. Peterson WL, American Gastroenterological Association Consensus Development Panel. Improving the management of GERD: Evidencebased therapeutic strategies. Richmond: AGA Press 2002:1-21.

32. Schnell TG, Sontag SJ, Chejfec G, et al. Long-term nonsurgical management of Barrett's esophagus with high-grade dysplasia. Gastroenterology 2001;120:1607-19.

33. Spechler SJ. Clinical practice. Barrett's Esophagus. N Engl J Med 2002;346:836-42.

34. Fass R, Hell RW, Garewal HS, et al. Correlation of oesophageal acid exposure with Barrett's oesophagus length. Gut 2001;48:310-3.

35. Fass R, Ofman JJ. Gastroesophageal reflux disease - should we adopt a new conceptual framework? Am J Gastroenterol 2002;97:1901-9.

36. Csendes A, Burdiles P, Braghetto I, et al. Dysplasia and adenocarcinoma after classic antireflux surgery in patients with Barrett's esophagus: The need for long-term subjective and objective follow-up. Ann Surg 2002;235:178-85.

37. Spechler SJ, Lee E, Ahnen D, et al. Long-term outcome of medical and surgical therapies for gastroesophageal reflux disease: Follow-up of a randomized controlled trial. JAMA 2001;285:2331-8.

38. Fennerty MB, Triadafilopoulos G. Barrett's-related esophageal adenocarcinoma: Is chemoprevention a potential option? Am J Gastroenterol 2001;96:2302-5.

39. Armstrong D. Motion - all patients with GERD should be offered once in a lifetime endoscopy: Arguments for the motion. Can J Gastroenterol 2002;16:549-51.

40. Sonnenberg A, Soni A, Sampliner RE. Medical decision analysis of endoscopic surveillance of Barrett's oesophagus to prevent oesophageal adenocarcinoma. Aliment Pharmacol Ther 2002;16:41-50.

41. Gudlaugsdottir S, van Blankenstein M, Dees J, Wilson JH. A majority of patients with Barrett's oesophagus are unlikely to benefit from endoscopic cancer surveillance. Eur J Gastroenterol Hepatol 2001;13:639-45.

42. Chiba N. Motion - screening and surveillance of Barrett's epithelium 
is practical and cost effective: Arguments against the motion. Can J Gastroenterol 2002;16:541-5.

43. Dent J, Brun J, Fendrick AM, et al. An evidence-based appraisal of reflux disease management - the Genval Workshop Report. Gut 1999;44(Suppl 2):S1-16.

44. Streitz JM Jr, Andrews CW Jr, Ellis FH Jr. Endoscopic surveillance of Barrett's esophagus. Does it help? J Thorac Cardiovasc Surg 1993;105:383-7.

45. van Sandick JW, van Lanschot JJ, Tytgat GN, Offerhaus GJ, Obertop H. Barrett oesophagus and adenocarcinoma: An overview of epidemiologic, conceptual and clinical issues. Scand J Gastroenterol 2001;234(Suppl):51-60.

46. Peters JH. The management of dysplastic Barrett's esophagus: Where do we go from here? Ann Surg Oncol 2002;9:215-6.

47. Macdonald CE, Wicks AC, Playford RJ. Final results from 10-year cohort of patients undergoing surveillance for Barrett's oesophagus: Observational study. BMJ 2000;321:1252-5.

48. Nietert PJ, Silverstein MD, Mokhashi MS, et al. Cost-effectiveness of screening a population with chronic gastroesophageal reflux. Gastrointest Endosc 2003;57:311-8.

49. Castell DO. Medical, surgical, and endoscopic treatment of gastroesophageal reflux disease and Barrett's esophagus. J Clin Gastroenterol 2001;33:262-6.

50. Peters FT, Ganesh S, Kuipers EJ, et al. Endoscopic regression of Barrett's oesophagus during omeprazole treatment; a randomised double blind study. Gut 1999;45:489-94. (Erratum in 2000;47:154-5).

51. Corey KE, Schmitz BA, Shaheen NJ. Does surgical antireflux procedure decrease the incidence of esophageal adenocarcinoma in Barret's esophagus? A meta-analysis. Am J Gastroenterol 2003;98:2390-4.

52. Stichtenoth DO, Frolich JC. The second generation of COX-2 inhibitors: What advantages do the newest offer? Drugs 2003;63:33-45.

53. Silverstein FE, Faich G, Goldstein JL, et al. Gastrointestinal toxicity with celecoxib vs nonsteroidal anti-inflammatory drugs for osteoarthritis and rheumatoid arthritis: The CLASS study: A randomized controlled trial. Celecoxib Long-term Arthritis Safety Study. JAMA 2000;284:1247-55.

54. Langman MJ, Jensen DM, Watson DJ, et al. Adverse upper gastrointestinal effects of rofecoxib compared with NSAIDs. JAMA 1999;282:1929-33.

55. MacDonald TM, Morant SV, Robinson GC, et al. Association of upper gastrointestinal toxicity of non-steroidal anti-inflammatory drugs with continued exposure: Cohort study. BMJ 1997;315:1333-7.

56. Garcia Rodriguez LA, Jick H. Risk of upper gastrointestinal bleeding and perforation associated with individual non-steroidal antiinflammatory drugs. Lancet 1994;343:769-72. Erratum in: Lancet 1994:343:1048

57. Ofman JJ, Maclean CH, Straus WL, et al. Meta-analysis of dyspepsia and nonsteroidal antiinflammatory drugs. Arthritis Rheum 2003;49:508-18.

58. Laheij RJ, Jansen JB, Verbeek AL, Verheugt FW. Helicobacter pylori infection as a risk factor for gastrointestinal symptoms in patients using aspirin to prevent ischaemic heart disease. Aliment Pharmacol Ther 2001;15:1055-9.

59. Derry S, Loke YK. Risk of gastrointestinal haemorrhage with long term use of aspirin: Meta-analysis. BMJ 2000;321:1183-7.

60. Straus WL, Ofman JJ, MacLean C, et al. Do NSAIDs cause dyspepsia? A meta-analysis evaluating alternative dyspepsia definitions. Am J Gastroenterol 2002;97:1951-8.

61. Bannwarth B, Treves R, Euller-Ziegler L, Rolland D, Ravaud P, Dougados M. Adverse events associated with rofecoxib therapy: Results of a large study in community-derived osteoarthritic patients. Drug Saf 2003;26:49-54.

62. Goldstein JL, Kivitz AJ, Verburg KM, Recker DP, Palmer RC, Kent JD. A comparison of the upper gastrointestinal mucosal effects of valdecoxib, naproxen and placebo in healthy elderly subjects. Aliment Pharmacol Ther 2003;18:125-32.

63. Wolfe F, Anderson J, Burke TA, Arguelles LM, Pettitt D. Gastroprotective therapy and risk of gastrointestinal ulcers: Risk reduction by COX-2 therapy. J Rheumatol 2002;29:467-73.

64. Makarowski W, Zhao WW, Bevirt T, Recker DP. Efficacy and safety of the COX-2 specific inhibitor valdecoxib in the management of osteoarthritis of the hip: A randomized, double-blind, placebocontrolled comparison with naproxen. Osteoarthritis Cartilage 2002;10:290-6

65. Sikes DH, Agrawal NM, Zhao WW, Kent JD, Recker DP, Verburg KM. Incidence of gastroduodenal ulcers associated with valdecoxib compared with that of ibuprofen and diclofenac in patients with osteoarthritis. Eur J Gastroenterol Hepatol 2002;14:1101-11.

66. Hunt RH, Harper S, Watson DJ, et al. The gastrointestinal safety of the COX-2 selective inhibitor etoricoxib assessed by both endoscopy and analysis of upper gastrointestinal events. Am J Gastroenterol 2003;98:1725-33.

67. Catella-Lawson F, Reilly MP, Kapoor SC, et al. Cyclooxygenase inhibitors and the antiplatelet effects of aspirin. N Engl J Med 2001;345:1809-17.

68. Huang JQ, Sridhar S, Hunt RH. Role of Helicobacter pylori infection and non-steroidal anti-inflammatory drugs in peptic-ulcer disease: A meta-analysis. Lancet 2002;359:14-22.

69. Lai KC, Lau CS, Ip WY, et al. Effect of treatment of Helicobacter pylori on the prevention of gastroduodenal ulcers in patients receiving long-term NSAIDs: A double-blind, placebo-controlled trial. Aliment Pharmacol Ther 2003;17:799-805

70. Graham DY. NSAIDs, Helicobacter pylori, and Pandora's box. N Eng J Med 2002;347:2162-4.

71. Lai KC, Lam SK, Chu KM, et al. Lansoprazole for the prevention of recurrences of ulcer complications from long-term low-dose aspirin use. N Engl J Med 2002;346:2033-8.

72. Holvoet J, Terriere L, Van Hee W, Verbist L, Fierens E, Hautekeete ML. Relation of upper gastrointestinal bleeding to nonsteroidal anti-inflammatory drugs and aspirin: A case-control study. Gut 1991;32:730-4

73. Clinch D, Banerjee AK, Ostick G. Absence of abdominal pain in elderly patients with peptic ulcer. Age Ageing 1984;13:120-3.

74. Mellem H, Stave R, Myren J, et al. Symptoms in patients with peptic ulcer and hematemesis and/or melena related to the use of nonsteroid anti-inflammatory drugs. Scand J Gastroenterol 1985;20:1246-8.

75. Matthewson K, Pugh S, Northfield TC. Which peptic ulcer patients bleed? Gut 1988;29:70-4

76. Laine L, Bombardier C, Hawkey CJ, et al. Stratifying the risk of NSAID-related upper gastrointestinal clinical events: Results of a double-blind outcomes study in patients with rheumatoid arthritis. Gastroenterology 2002;123:1006-12.

77. Chalmers TC, Berrier J, Hewitt P, et al. Meta-analysis of randomized controlled trials as a method of estimating rare complications of nonsteroidal anti-inflammatory drug therapy. Aliment Pharmacol Ther 1988;2(Suppl 1):9-26.

78. Gabriel SE, Jaakkimainen L, Bombardier C. Risk for serious gastrointestinal complications related to use of nonsteroidal antiinflammatory drugs. A meta-analysis. Ann Intern Med 1991;115:787-96.

79. van Pinxteren B, Numans ME, Lau J, de Wit NJ, Hungin AP, Bonis PA. Short-term treatment of gastroesophageal reflux disease. J Gen Intern Med 2003;18:755-63.

80. Chiba N, De Gara CJ, Wilkinson JM, Hunt RH. Speed of healing and symptom relief in grade II to IV gastroesophageal reflux disease: A meta-analysis. Gastroenterology 1997;112:1798-810.

81. Vigneri S, Termini R, Leandro G, et al. A comparison of five maintenance therapies for reflux esophagitis. N Engl J Med 1995;333:1106-10

82. Galmiche JP, Barthelemy P, Hamelin B. Treating the symptoms of gastro-oesophageal reflux disease: A double-blind comparison of omeprazole and cisapride. Aliment Pharmacol Ther 1997;11:765-73.

83. Armstrong D, Barkun AN, Chiba N, et al, and CADET HR Investigators. Initial PPI therapy is most effective in the management of heartburn-dominant uninvestigated dyspepsia (UD) in primary care practice (PCP) - The CADET-HR study. Can J Gastroenterol 2002;16(Suppl A):97A. (Abst)

84. Venables TL, Newland RD, Patel AC, Hole J, Wilcock C,Turbitt ML. Omeprazole 10 milligrams once daily, omeprazole 20 milligrams once daily, or ranitidine 150 milligrams twice daily, evaluated as initial 
therapy for the relief of symptoms of gastro-oesophageal reflux disease in general practice. Scand J Gastroenterol 1997;32:965-73.

85. Carlsson R, Dent J, Watts R, et al. Gastro-oesophageal reflux disease in primary care: An international study of different treatment strategies with omeprazole. International GORD Study Group. Eur J Gastroenterol Hepatol 1998;10:119-24.

86. Lind T, Havelund T, Carlsson R, et al. Heartburn without oesophagitis: Efficacy of omeprazole therapy and features determining therapeutic response. Scand J Gastroenterol 1997;32:974-9.

87. Vakil N, Fennerty MB. Direct comparative trials of the efficacy of proton pump inhibitors in the management of gastro-oesophageal reflux disease and peptic ulcer disease. Aliment Pharmacol Ther 2003; 18:559-68.

88. Edwards SJ, Lind T, Lundell L. Systematic review of proton pump inhibitors for the acute treatment of reflux oesophagitis. Aliment Pharmacol Ther 2001;15:1729-36.

89. Klok RM, Postma MJ, van Hout BA, Brouwers JR. Meta-analysis: Comparing the efficacy of proton pump inhibitors in short-term use. Aliment Pharmacol Ther 2003;17:1237-45.

90. Armstrong D, Veldhuyzen van Zanten SJO, Barkun AN, et al, and the CAST Study Investigators. Symptom response at one week to predict outcome at four weeks with esomeprazole (E) in heartburndominant uninvestigated dyspepsia (HBDUD) patients: The confirmatory acid suppression (CAST) test. Can J Gastroenterol 2003;17(Suppl A):A85. (Abst)

91. van Bommel MJ, Numans ME, de Wit NJ, Stalman WA. Consultations and referrals for dyspepsia in general practice - a one year database survey. Postgrad Med J 2001;77:514-8.

92. Majumdar SR, Soumerai SB, Francis FA, et al. Chronic acid-related disorders are common and underinvestigated. Am J Gastroenterol 2003;98:2409-14.

93. Jacobson BC, Ferris TG, Shea TL, Mahlis EM, Lee TH, Wang TC. Who is using chronic acid suppression therapy and why? Am J Gastroenterol 2003;98:51-8.

94. Hansen JM, Bytzer P, Bondesen S, Schaffalitzky de Muckadell OB. Efficacy and outcome of an open access endoscopy service. Dan Med Bull 1991;38:288-90.

95. Quadri A, Vakil N. Health-related anxiety and the effect of openaccess endoscopy in US patients with dyspepsia. Aliment Pharmacol Ther 2003;17:835-40.

96. Fennerty MB. The continuum of GERD complications. Cleve Clin J Med 2003;70(Suppl 5):S33-50.

97. Locke GR III. Natural history of nonerosive reflux disease. Is all gastroesophageal reflux disease the same? What is the evidence? Gastroenterol Clin North Am 2002;31(Suppl 4):S59-66.

98. Talley NJ. Natural history of reflux esophagitis: What is the risk of progression and does it matter clinically? Gastroenterol Hepatol 2002;17:1247-9.

99. Manabe N, Yoshihara M, Sasaki A, Tanaka S, Haruma K, Chayama K. Clinical characteristics and natural history of patients with low-grade reflux esophagitis. J Gastroenterol Hepatol 2002;17:949-54.

100. Klinkenberg-Knol EC, Festen HP, Meuwissen SG. Pharmacological management of gastro-oesophageal reflux disease. Drugs 1995;49:695-710.

101. Dent J, Talley NJ. Overview: Initial and long-term management of gastro-oesophageal reflux disease. Aliment Pharmacol Ther 2003;17(Suppl 1):53-7.

102. Maton PN. Profile and assessment of GERD pharmacotherapy. Cleve Clin J Med 2003;70(Suppl 5):S51-70.

103. Tutuian R, Castell DO. Management of gastroesophageal reflux disease. Am J Med Sci 2003;326:309-18.

104. Lamberts R, Brunner G, Solcia E. Effects of very long (up to 10 years) proton pump blockade on human gastric mucosa. Digestion 2001;64:205-13.

105. Howden CW. Potent versus mild acid suppression in peptic ulcer disease. Hepatogastroenterology 1992;39(Suppl 1):45-6.

106. Freston JW. Long-term acid control and proton pump inhibitors: Interactions and safety issues in perspective. Am J Gastroenterol 1997;92(Suppl 4):51S-7S.

107. Howden CW, Henning JM, Huang B, Lukasik N, Freston JW. Management of heartburn in a large, randomized, community-based study: Comparison of four therapeutic strategies. Am J Gastroenterol 2001;96:1704-10. (Erratum in 2001;96:2809).

108. Inadomi JM, Jamal R, Murata GH, et al. Step-down management of gastroesophageal reflux disease. Gastroenterology 2001;121:1095-100.

109. Bardhan KD, Muller-Lissner S, Bigard MA, et al. Symptomatic gastro-oesophageal reflux disease: Double blind controlled study of intermittent treatment with omeprazole or ranitidine. The European Study Group. BMJ 1999;318:502-7.

110. Quartero AO, Numans ME, Post MW, de Melker RA, de Wit NJ. One-year prognosis of primary care dyspepsia: Predictive value of symptom pattern, Helicobacter pylori and GP management. Eur J Gastroenterol Hepatol 2002;14:55-60.

111. Lind T, Havelund T, Lundell L, et al. On demand therapy with omeprazole for the long-term management of patients with heartburn without oesophagitis - a placebo-controlled randomized trial. Aliment Pharmacol Ther 1999;13:907-14.

112. Talley NJ, Venables TL, Green JR, et al. Esomeprazole $40 \mathrm{mg}$ and $20 \mathrm{mg}$ is efficacious in the long-term management of patients with endoscopy-negative gastro-oesophageal reflux disease: A placebocontrolled trial of on-demand therapy for 6 months. Eur J Gastroenterol Hepatol 2002;14:857-63.

113. Wahlqvist P, Junghard $O$, Higgins A, Green J. Cost effectiveness of proton pump inhibitors in gastro-oesophageal reflux disease without oesophagitis: Comparison of on-demand esomeprazole with conventional omeprazole strategies. Pharmacoeconomics 2002;20:267-77.

114. Bytzer P. On-demand therapy for gastro-oesophageal reflux disease. Eur J Gastroenterol Hepatol 2001;13(Suppl 1):S19-22.

115. Porro GB, Pace F. Rationale and efficacy of medical therapy for gastrooesophageal reflux disease. J Intern Med 1993;234:387-96.

116. Zacny J, Zamakhshary M, Veldhuyzen van Zanten S. A systematic review of the efficacy of intermittent and on-demand therapy with histamine $\mathrm{H}_{2}$-receptor antagonists or proton pump inhibitors for GERD patients. Aliment Pharmacol Ther 2005 (In press)

117. Spechler SJ. Comparison of medical and surgical therapy for complicated gastroesophageal reflux disease in veterans. The Department of Veterans Affairs Gastroesophageal Reflux Study Group. N Engl J Med 1992;326:786-92.

118. Campos GM, Peters JH, DeMeester TR, et al. Multivariate analysis of factors predicting outcomes after laparoscopic Nissen fundoplication. J Gastrointest Surg 1999;3:292-300.

119. McMahon RL, Mercer CD. National trends in gastroesophageal reflux surgery. Can J Surg 2000;43:48-52.

120. Nilsson G, Larsson S, Johnsson F. Randomized clinical trial of laparoscopic versus open fundoplication: Evaluation of psychological well-being and changes in everyday life from a patient perspective. Scand J Gastroenterol 2002;37:385-91.

121. Chrysos E, Tsiaoussis J, Athanasakis E, Zoras O, Vassilakis JS, Xynos E. Laparoscopic vs open approach for Nissen fundoplication. A comparative study. Surg Endosc 2002;16:1679-84.

122. Wenner J, Nilsson G, Oberg S, Melin T, Larsson S, Johnsson F. Short-term outcome after laparoscopic and open 360 degrees fundoplication. A prospective randomized trial. Surg Endosc 2001;15:1124-8.

123. Luostarinen M, Virtanen J, Koskinen M, Matikainen M, Isolauri J. Dysphagia and oesophageal clearance after laparoscopic versus open Nissen fundoplication. A randomized, prospective trial. Scand J Gastroenterol 2001;36:565-71.

124. Nilsson G, Larsson S, Johnsson F. Randomized clinical trial of laparoscopic versus open fundoplication: Blind evaluation of recovery and discharge period. Br J Surg 2000;87:873-8.

125. Bais JE, Bartelsman JF, Bonjer HJ, et al. Laparoscopic or conventional Nissen fundoplication for gastro-oesophageal reflux disease: Randomised clinical trial. The Netherlands Antireflux Surgery Study Group. Lancet 2000;355:170-4.

126. Heikkinen TJ, Haukipuro K, Bringman S, Ramel S, Sorasto A, Hulkko A. Comparison of laparoscopic and open Nissen fundoplication 2 years after operation. A prospective randomized trial. Surg Endosc 2000;14:1019-23.

127. Lundell L, Miettinen P, Myrvold HE, et al. Continued (5-year) follow-up of a randomized clinical study comparing antireflux surgery 
and omeprazole in gastroesophageal reflux disease. J Am Coll Surg 2001;192:172-81

128. Triadafilopoulos G, DiBaise JK, Nostrant TT, et al. The Stretta procedure for the treatment of GERD: 6 and 12 month follow-up of the US open label trial. Gastrointest Endosc 2002;55:149-56.

129. Johnson DA, Ganz R, Aisenberg J, et al. Endoscopic implantation of enteryx for treatment of GERD: 12-month results of a prospective, multicenter trial. Am J Gastroenterol 2003;98:1921-30.

130. Fennerty MB. Endoscopic suturing for treatment of GERD. Gastrointest Endosc 2003;57:390-5.

131. Raghunath A, Hungin AP, Wooff D, Childs S. Prevalence of Helicobacter pylori in patients with gastro-oesophageal reflux disease: Systematic review. BMJ 2003;326:737.

132. Sharma P, Vakil N. Review article: Helicobacter pylori and reflux disease. Aliment Pharmacol Ther 2003;17:297-305.

133. Vigneri S, Termini R, Savarino V, Pace F. Review article: Is Helicobacter pylori status relevant in the management of GORD? Aliment Pharmacol Ther 2000;14(Suppl 3):31-42.

134. Malfertheiner P, Gerards C. Helicobacter pylori infection and gastrooesophageal reflux disease: Coincidence or association? Baillieres Best Pract Res Clin Gastroenterol 2000;14:731-41.

135. Labenz J, Blum AL, Bayerdorffer E, Meining A, Stolte M, Borsch G. Curing Helicobacter pylori infection in patients with duodenal ulcer may provoke reflux esophagitis. Gastroenterology 1997;112:1442-7.

136. Morini S, Zullo A, Hassan C, Lorenzetti R, Stella F, Martini MT. Gastric cardia inflammation: Role of Helicobacter pylori infection and symptoms of gastroesophageal reflux disease. Am J Gastroenterol 2001;96:2337-40.

137. Schwizer W, Thumshim M, Dent J, et al. Helicobacter pylori and symptomatic relapse of gastro-oesophageal reflux disease: A randomized controlled trial. Lancet 2001;357:1738-42.

138. Verma S, Giaffer MH. Helicobacter pylori eradication ameliorates symptoms and improves quality of life in patients on long-term acid suppression. A large prospective study in primary care. Dig Dis Sci 2002;47:1567-74.

139. Moayyedi P, Bardhan C, Young L, Dixon MF, Brown L, Axon AT. Helicobacter pylori eradication does not exacerbate reflux symptoms in gastroesophageal reflux disease. Gastroenterology 2001;121:1120-6.

140. Cremonini F, Di Caro S, Delgado-Aros S, et al. Meta-analysis: The relationship between Helicobacter pylori infection and gastrooesophageal reflux disease. Aliment Pharmacol Ther 2003;18:279-89.

141. Kuipers EJ, Lundell L, Klinkenberg-Knol EC, et al. Atrophic gastritis and Helicobacter pylori infection in patients with reflux esophagitis treated with omeprazole or fundoplication. N Engl J Med 1996;334:1018-22.

142. Yamada T, Miwa H, Fujino T, Hirai S, Yokoyama T, Sato N. Improvement of gastric atrophy after Helicobacter pylori eradication therapy. J Clin Gastroenterol 2003;36:405-10.

143. Ohkusa T, Fujiki K, Takashimizu I, et al. Improvement in atrophic gastritis and intestinal metaplasia in patients in whom Helicobacter pylori was eradicated. Ann Intern Med 2001;134:380-6.

144. Satoh K. Does eradication of Helicobacter pylori reverse atrophic gastritis or intestinal metaplasia? Data from Japan. Gastroenterol Clin North Am 2000;29:829-35.

145. Ohkuma K, Okada M, Murayama H, et al. Association of Helicobacter pylori infection with atrophic gastritis and intestinal metaplasia. J Gastroenterol Hepatol 2000;15:1105-12.

146. Kim N, Lim SH, Lee KH, Choi SE. Long-term effect of Helicobacter pylori eradication on gastric metaplasia in patients with duodenal ulcer. J Clin Gastroenterol 1998;27:246-52.

147. DeLuca VA Jr, West AB, Haque S, et al. Long-term symptom patterns, endoscopic findings, and gastric histology in Helicobacter pylori-infected and -uninfected patients. J Clin Gastroenterol 1998;26:106-12.

148. Zhou L, Sung JJ, Lin S, et al. A five-year follow-up study on the pathological changes of gastric mucosa after $\mathrm{H}$ pylori eradication. Chin Med J (Engl) 2003;116:11-4.

149. Satoh K, Kimura K, Takimoto T, Kihira K. A follow-up study of atrophic gastritis and intestinal metaplasia after eradication of Helicobacter pylori. Helicobacter 1998;3:236-40.
150. Moayyedi P, Feltbower R, Brown J, et al. Effect of population screening and treatment for Helicobacter pylori on dyspepsia and quality of life in the community: A randomised controlled trial. Leeds HELP Study Group. Lancet 2000;355:1665-9.

151. Moayyedi P, Soo S, Deeks J, et al. Eradication of Helicobacter pylori for non-ulcer dyspepsia. Cochrane Database Syst Rev 2001;(1):CD002096. (Update in: Cochrane Database Syst Rev 2003;(1):CD002096).

152. Wildner-Christensen M, Moller Hansen J, Schaffalitzky De Muckadell OB. Rates of dyspepsia one year after Helicobacter pylori screening and eradication in a Danish population. Gastroenterology 2003;125:372-9.

153. Manes G, Menchise A, de Nucci C, Balzano A. Empirical prescribing for dyspepsia: Randomised controlled trial of test and treat versus omeprazole treatment. BMJ 2003;326:1118.

154. Graham DY. Can therapy even be denied for Helicobacter pylori infection? Gastroenterology 1997;113(Suppl 6):S113-7.

155. Kuipers EJ, Thijs JC, Festen HP. The prevalence of Helicobacter pylori in peptic ulcer disease. Aliment Pharmacol Ther 1995;9(Suppl 2):59-69.

156. Laine L, Hunt R, El-Zimaity H, Nguyen B, Osato M, Spenard J. Bismuth-based quadruple therapy using a single capsule of bismuth biskalcitrate, metronidazole, and tetracycline given with omeprazole versus omeprazole, amoxicillin, and clarithromycin for eradication of Helicobacter pylori in duodenal ulcer patients: A prospective, randomized, multicenter, North American trial. Am J Gastroenterol 2003;98:562-7.

157. Bardhan K, Bayerdorffer E, Veldhuyzen Van Zanten SJ, et al. The HOMER Study: The effect of increasing the dose of metronidazole when given with omeprazole and amoxicillin to cure Helicobacter pylori infection. Helicobacter 2000;5:196-201.

158. Veldhuyzen van Zanten S, Hunt RH, Cockeram A, et al. Adding once-daily omeprazole $20 \mathrm{mg}$ to metronidazole/amoxicillin treatment for Helicobacter pylori gastritis: A randomized, double-blind trial showing the importance of metronidazole resistance. Am J Gastroenterol 1998;93:5-10.

159. Best LM, Haldane DJM, Veldhuyzen van Zanten SJO. Susceptibility of Canadian Strains of Helicobacter pylori to metronidazole and clarithromycin using four assay methods. Can J Gastroenterol 1998;12(Suppl A):106A(S92).

160. Fallone CA. Epidemiology of the antibiotic resistance of Helicobacter pylori in Canada. Can J Gastroenterol 2000;14:879-82.

161. Gisbert JP, Gonzalez L, Calvet X, et al. Proton pump inhibitor, clarithromycin and either amoxycillin or nitroimidazole: A metaanalysis of eradication of Helicobacter pylori. Aliment Pharmacol Ther 2000;14:1319-28

162. Laheij RJF, Rossum LG, Jansen JB, Straatman H, Verbeek AL. Evaluation of treatment regimens to cure Helicobacter pylori infection - a meta-analysis. Aliment Pharmacol Ther 1999;13:857-64.

163. Fischbach LA, Goodman KJ, Feldman M, Aragaki C. Sources of variation of Helicobacter pylori treatment success in adults worldwide: A meta-analysis. Int J Epidemiol 2002;31:128-39.

164. Katelaris PH, Forbes GM, Talley NJ, Crotty B. A randomized comparison of quadruple and triple therapies for Helicobacter pylori eradication: The QUADRATE Study. Gastroenterology 2002;123:1763-9.

165. Vergara M, Vallve M, Gisbert JP, Calvet X. Meta-analysis: Comparative efficacy of different proton-pump inhibitors in triple therapy for Helicobacter pylori eradication. Aliment Pharmacol Ther 2003;18:647-54.

166. Hunt R, Thomson AB. Canadian Helicobacter pylori consensus conference. Canadian Association of Gastroenterology. Can J Gastroenterol 1998;12:31-41.

167. Graham DY, Hammoud F, El-Zimaity HM, Kim JG, Osato MS, El-Serag HB. Meta-analysis: Proton pump inhibitor or $\mathrm{H}_{2}$-receptor antagonist for Helicobacter pylori eradication. Aliment Pharmacol Ther 2003;17:1229-36.

168. Gisbert JP, Pajares JM. Review article: Helicobacter pylori "rescue" regimen when proton pump inhibitor-based triple therapies fail. Aliment Pharmacol Ther 2002;16:1047-57.

169. Graham DY, Opekun AR, Hammoud F, et al. Studies regarding the 
mechanism of false negative urea breath tests with proton pump inhibitors. Am J Gastroenterol 2003;98:1005-9.

170. Chiba N, Veldhuyzen Van Zanten SJ. 13C-Urea breath tests are the noninvasive method of choice for Helicobacter pylori detection. Can J Gastroenterol 1999;13:681-3.

171. Malfertheiner P, Megraud F, O’Morain C, et al; European Helicobacter Pylori Study Group (EHPSG). Current concepts in the management of Helicobacter pylori infection - the Maastricht 2-2000 Consensus Report. Aliment Pharmacol Ther 2002;16:167-80.

172. Mirshahi F, Fowler G, Patel A, Shaw G. Omeprazole may exert both a bacteriostatic and a bacteriocidal effect on the growth of Helicobacter pylori (NCTC 11637) in vitro by inhibiting bacterial urease activity. J Clin Pathol 1998;51:220-4.

173. Nakao M, Malfertheiner P. Growth inhibitory and bactericidal activities of lansoprazole compared with those of omeprazole and pantoprazole against Helicobacter pylori. Helicobacter 1998;3:21-7.

174. Savarino V, Bisso G, Pivari M, et al. Effect of omeprazole and ranitidine on the accuracy of 13C-urea breath test (UBT). Gut 1998;43:A51 (Abst)

175. Savarino V, Vigneri S, Celle G. The $13 \mathrm{C}$ urea breath test in the diagnosis of Helicobacter pylori infection. Gut 1999;45(Suppl 1):I18-22.

176. Dulbecco P, Gambaro C, Bilardi C, et al. Impact of long-term ranitidine and pantoprazole on accuracy of [13C] urea breath test. Dig Dis Sci 2003;48:315-21.

177. Chey WD, Spybrook M, Carpenter S, et al. Prolonged effect of omeprazole on the 14C-urea breath test. Am J Gastroenterol 1996;91:89-92.

178. Katelaris PH, Connor SJ, Seow F, et al. The effect of short-term omeprazole use on the accuracy of 13C-urea breath test in Helicobacter pylori infected patients. Gut 1998;43(Suppl 2):A53. (Abst)

179. Laine L, Estrada R, Trujillo M, Knigge K, Fennerty MB. Effect of proton-pump inhibitor therapy on diagnostic testing of Helicobacter pylori. Ann Intern Med 1998;129:547-50.

180. El-Nujumi A, Hilditch TE, Williams C, McColl KE. Current or recent proton pump inhibitor therapy markedly impairs the accuracy of the [14C] urea breath test. Eur J Gastroenterol Hepatol 1998; 10:759-64.

181. McColl KE, el-Nujumi A, Murray L, et al. The Helicobacter pylori breath test: A surrogate marker for peptic ulcer disease in dyspeptic patients. Gut 1997;40:302-6.

182. Chey WD, Woods M, Scheiman JM, Nostrant TT, DelValle J. Lansoprazole and ranitidine affect the accuracy of the 14C-urea breath test by a $\mathrm{pH}$-dependent mechanism. Am J Gastroenterol 1997;92:446-50.

183. Cutler AF, Elnaggar M, Brooks E, O'Mara K. Effect of standard and high dose ranitidine on $[13 \mathrm{C}]$ urea breath test results. Am J Gastroenterol 1998;93:1297-9.

184. Savarino V, Tracci D, Dulbecco P, et al. Negative effect of ranitidine on the results of urea breath test for the diagnosis of Helicobacter pylori. Am J Gastroenterol 2001;96:348-52.

185. Soo S, Moayyedi P, Deeks J, Delaney B, Innes M, Forman D. Pharmacological interventions for non-ulcer dyspepsia. Cochrane Database Syst Rev 2000;(2):CD001960. (Update in: Cochrane Database Syst Rev 2003;(1):CD001960).

186. Bolling-Sternevald E, Lauritsen K, Aalykke C, et al. Effect of profound acid suppression in functional dyspepsia: A double-blind, randomized, placebo-controlled trial. Scand J Gastroenterol 2002;37:1395-402.

187. Talley NJ, Meineche-Schmidt V, Pare P, et al. Efficacy of omeprazole in functional dyspepsia: Double-blind, randomized, placebocontrolled trials (the Bond and Opera studies). Aliment Pharmacol Ther 1998;12:1055-65.

188. Veldhuyzen van Zanten S, Chiba N, Armstrong D, et al, and CADET-HN Investigators. A double-blind randomised controlled trial comparing omeprazole (Ome), ranitidine (Ran), cisapride (Cis) and placebo (Pla) in 512 Helicobacter pylori ( $\mathrm{Hp}$ ) negative primary care patients with uninvestigated dyspepsia (UD) - The CADETHN Study. Can J Gastroenterol 2002;16(Suppl A):5A. (Abst)

189. Delaney BC, Innes MA, Deeks J, et al. Initial management strategies for dyspepsia. Cochrane Database Syst Rev 2001;(3):CD001961. (Update in: Cochrane Database Syst Rev 2003;(2):CD001961).

190. Moayyedi P, Soo S, Deeks J, Delaney B, Innes M, Forman D.
Pharmacological interventions for non-ulcer dyspepsia. Cochrane Database Syst Rev 2003;(1):CD001960. (Updated in: Database Syst Rev 2003;(2):CD001961).

191. Veldhuyzen van Zanten SJ, Jones MJ, Verlinden M, Talley NJ. Efficacy of cisapride and domperidone in functional (nonulcer) dyspepsia: A meta-analysis. Am J Gastroenterol 2001;96:689-96.

192. Hatlebakk JG, Katz PO, Camacho-Lobato L, Castell DO. Proton pump inhibitors: Better acid suppression when taken before a meal than without a meal. Aliment Pharmacol Ther 2000;14:1267-72.

193. Katz PO, Hatlebakk JG, Castell DO. Gastric acidity and acid breakthrough with twice-daily omeprazole or lansoprazole. Aliment Pharmacol Ther 2000;14:709-14.

194. Hatlebakk JG, Katz PO, Kuo B, Castell DO. Nocturnal gastric acidity and acid breakthrough on different regimens of omeprazole 40 mg daily. Aliment Pharmacol Ther 1998;12:1235-40.

195. Chiverton SG, Howden CW, Burget DW, Hunt RH. Omeprazole (20 mg) daily given in the morning or evening: A comparison of effects on gastric acidity, and plasma gastrin and omeprazole concentration. Aliment Pharmacol Ther 1992;6:103-11.

196. Tougas G, Chen Y, Hwang P, Liu MM, Eggleston A. Prevalence and impact of upper gastrointestinal symptoms in the Canadian population: Findings from the DIGEST study. Domestic/International Gastroenterology Surveillance Study. Am J Gastroenterol 1999;94:2845-54.

197. Maton PN, Burton ME. Antacids revisited. A review of their clinical pharmacology and recommended therapeutic use. Drugs 1999;57:855-70.

198. Mullane J, Fung K, Starkey P, et al. A comparison of the effect of a single dose of either calcium carbonate $(1 \mathrm{~g})$ or famotidine $(10 \mathrm{mg})$ on intragastric $\mathrm{pH}$ in normal healthy subjects. Gastroenterology 1997;112:A246. (Abst)

199. Collings KL, Rodriguez-Stanley S, Proskin HM, Robinson M, Miner PB Jr. Clinical effectiveness of a new antacid chewing gum on heartburn and oesophageal pH control. Aliment Pharmacol Ther 2002;16:2029-35.

200. Robinson M, Rodriguez-Stanley S, Miner PB, McGuire AJ, Fung K, Ciociola AA. Effects of antacid formulation on postprandial oesophageal acidity in patients with a history of episodic heartburn. Aliment Pharmacol Ther 2002;16:435-43.

201. Reilly TG, Mann SG, Panos MZ, Walt RP. Low-dose famotidine and cimetidine in single post-prandial doses: A placebo controlled comparative study of overnight pH. Gut 1995;37:325-8.

202. Hamilton MI, Sercombe J, Pounder RE. Decrease of intragastric acidity in healthy subjects dosed with ranitidine $75 \mathrm{mg}$, cimetidine $200 \mathrm{mg}$, or placebo. Dig Dis Sci 2002;47:54-7.

203. Sihvo S, Hemminki E. Self-medication of dyspepsia: How appropriate is it? Scand J Gastroenterol 1997;32:855-61.

204. Mandel KG, Daggy BP, Brodie DA, Jacoby HI. Review article: Alginate-raft formulations in the treatment of heartburn and acid reflux. Aliment Pharmacol Ther 2000;14:669-90.

205. Mann SG, Murakami A, McCarroll K, et al. Low dose famotidine in the prevention of sleep disturbance caused by heartburn after an evening meal. Aliment Pharmacol Ther 1995;9:395-401.

206. Paul K, Redman CM, Chen M. Effectiveness and safety of nizatidine, $75 \mathrm{mg}$, for the relief of episodic heartburn. Aliment Pharmacol Ther 2001;15:1571-7.

207. Feldman M. Comparison of the effects of over-the-counter famotidine and calcium carbonate antacid on postprandial gastric acid. A randomized controlled trial. JAMA 1996;275:1428-31.

208. Thompson Coon J, Ernst E. Systematic review: Herbal medicinal products for non-ulcer dyspepsia. Aliment Pharmacol Ther 2002;16:1689-99.

209. Broussard CN, Richter JE. Treating gastro-oesophageal reflux disease during pregnancy and lactation: What are the safest therapy options? Drug Saf 1998;19:325-37.

210. Winbery SL, Blaho KE. Dyspepsia in pregnancy. Obstet Gynecol Clin North Am 2001;28:333-50.

211. Adams S. Understanding indigestion and GORD. Prof Care Mother Child 1999;9:143-6.

212. Alvarez-Sanchez A, Rey E, Achem SR, Diaz-Rubio M. Does progesterone fluctuation across the menstrual cycle predispose to gastroesophageal reflux? Am J Gastroenterol 1999;94:1468-71. 
213. Dajani EZ. Gastroesophageal reflux disease: Pathophysiology and pharmacology overview. J Assoc Acad Minor Phys 2000;11:7-11.

214. Nikfar S, Abdollahi M, Moretti ME, Magee LA, Koren G. Use of proton pump inhibitors during pregnancy and rates of major malformations: A meta-analysis. Dig Dis Sci 2002;47:1526-9.

215. Larson JD, Patatanian E, Miner PB Jr, Rayburn WF, Robinson MG. Double-blind, placebo-controlled study of ranitidine for gastroesophageal reflux symptoms during pregnancy. Obstet Gynecol 1997;90:83-7.

216. Williamson C. Drugs in pregnancy. Gastrointestinal disease. Best Pract Res Clin Obstet Gynaecol 2001;15:937-52.

217. Atallah AN, Hofmeyr GJ, Duley L. Calcium supplementation during pregnancy for preventing hypertensive disorders and related problems. Cochrane Database Syst Rev 2000;1:CD001059.

218. Candelli M, Carloni E, Armuzzi A, et al. Role of sucralfate in gastrointestinal diseases. Panminerva Med 2000;42:55-9.

219. Henry A, Crowther C. Patterns of medication use during and prior to pregnancy: The MAP study. Aust N Z J Obstet Gynaecol 2000;40:165-72.

220. Kennie N, Por CP, Evans MF. Does ranitidine work for gastroesophageal symptoms during pregnancy? Can Fam Physician 1998;44:761-2.

221. Rayburn W, Liles E, Christensen H, Robinson M. Antacids vs antacids plus non-prescription ranitidine for heartburn during pregnancy. Int J Gynaecol Obstet 1999;66:35-7.

222. Ruigomez A, Garcia Rodriguez LA, Cattaruzzi C, et al. Use of cimetidine, omeprazole, and ranitidine in pregnant women and pregnancy outcomes. Am J Epidemiol 1999;150:476-81.

223. Lalkin A, Loebstein R, Addis A, et al. The safety of omeprazole during pregnancy: A multicenter prospective controlled study. Am J Obstet Gynecol 1998;179:727-30.
224. Gastro-oesophageal reflux during pregnancy: Treat with care. Drug Ther Perspect 1999;13:7-11.

225. Marshall JK, Thompson AB, Armstrong D. Omeprazole for refractory gastroesophageal reflux disease during pregnancy and lactation. Can J Gastroenterol 1998;12:225-7.

226. Soo S, Moayyedi P, Deeks J, Delaney B, Lewis M, Forman D. Psychological interventions for non-ulcer dyspepsia. Cochrane Database Syst Rev 2001;(4):CD002301.

227. Lee S, Park M, Choi S, Nah Y, Abbey SE, Rodin G. Stress, coping, and depression in non-ulcer dyspepsia patients. J Psychosom Res 2000;49:93-9.

228. Drossman DA. Importance of the psyche in heartburn and dyspepsia. Aliment Pharmacol Ther 1997;11(Suppl 2):57-67.

229. Wiklund I, Butler-Wheelhouse P. Psychosocial factors and their role in symptomatic gastroesophageal reflux disease and functional dyspepsia. Scand J Gastroenterol Suppl 1996;220:94-100.

230. O'Malley PG, Jackson JL, Santoro J, Tomkins G, Balden E, Kroenke K. Antidepressant therapy for unexplained symptoms and symptom syndromes. J Fam Pract 1999;48:980-90.

231. de Abajo FJ, Rodriguez LA, Montero D. Association between selective serotonin reuptake inhibitors and upper gastrointestinal bleeding: Population based case-control study. BMJ 1999;319:1106-9.

232. van Walraven C, Mamdani MM, Wells PS, Williams JI. Inhibition of serotonin reuptake by antidepressants and upper gastrointestinal bleeding in elderly patients: Retrospective cohort study. BMJ 2001;323:655-8.

233. Hamilton J, Guthrie E, Creed F, et al. A randomized controlled trial of psychotherapy in patients with chronic functional dyspepsia. Gastroenterology 2000;119:661-9. 


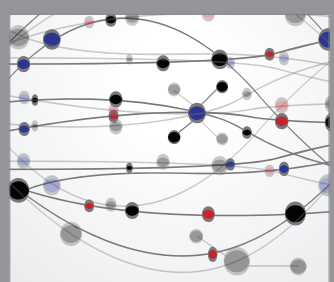

The Scientific World Journal
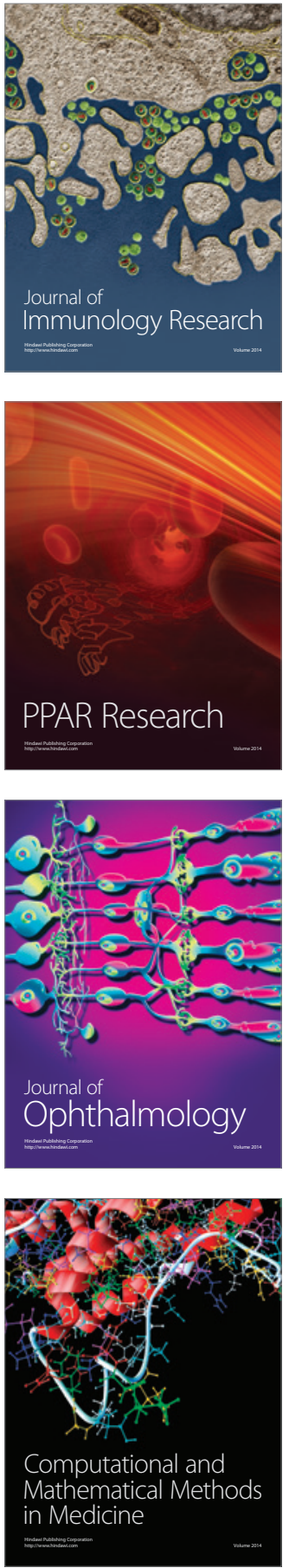

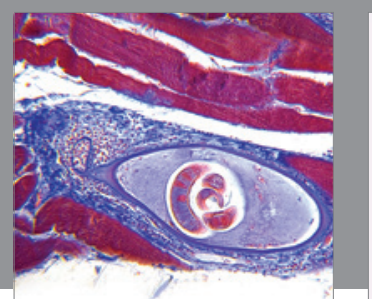

Gastroenterology Research and Practice

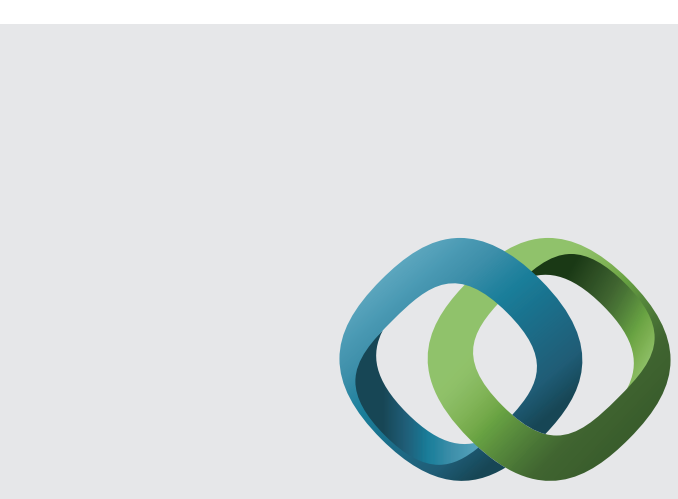

\section{Hindawi}

Submit your manuscripts at

http://www.hindawi.com
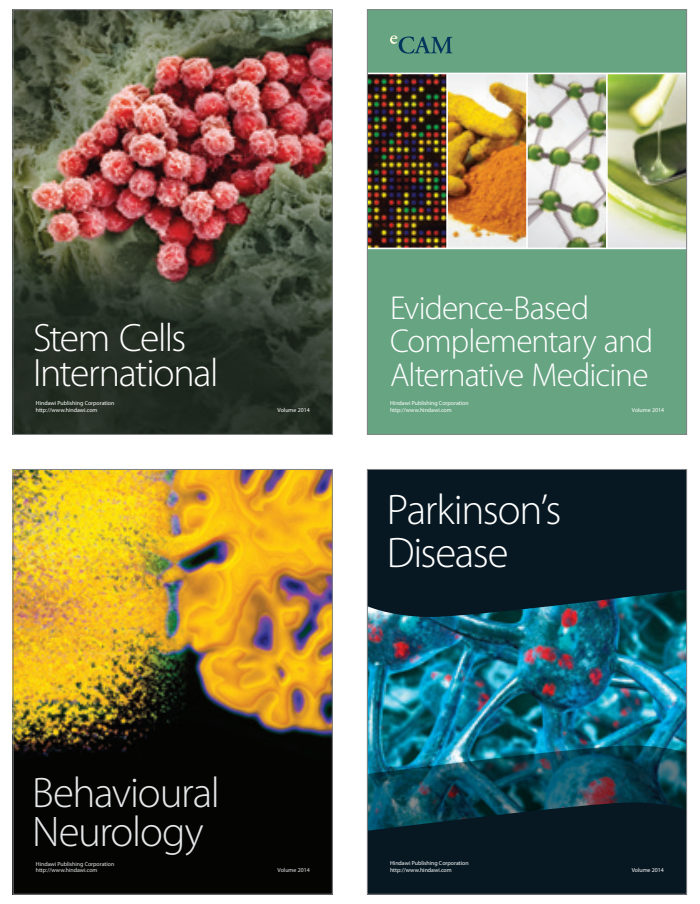
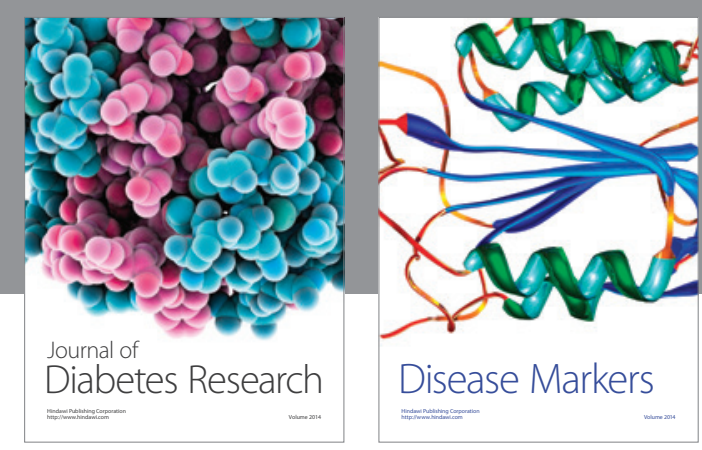

Disease Markers
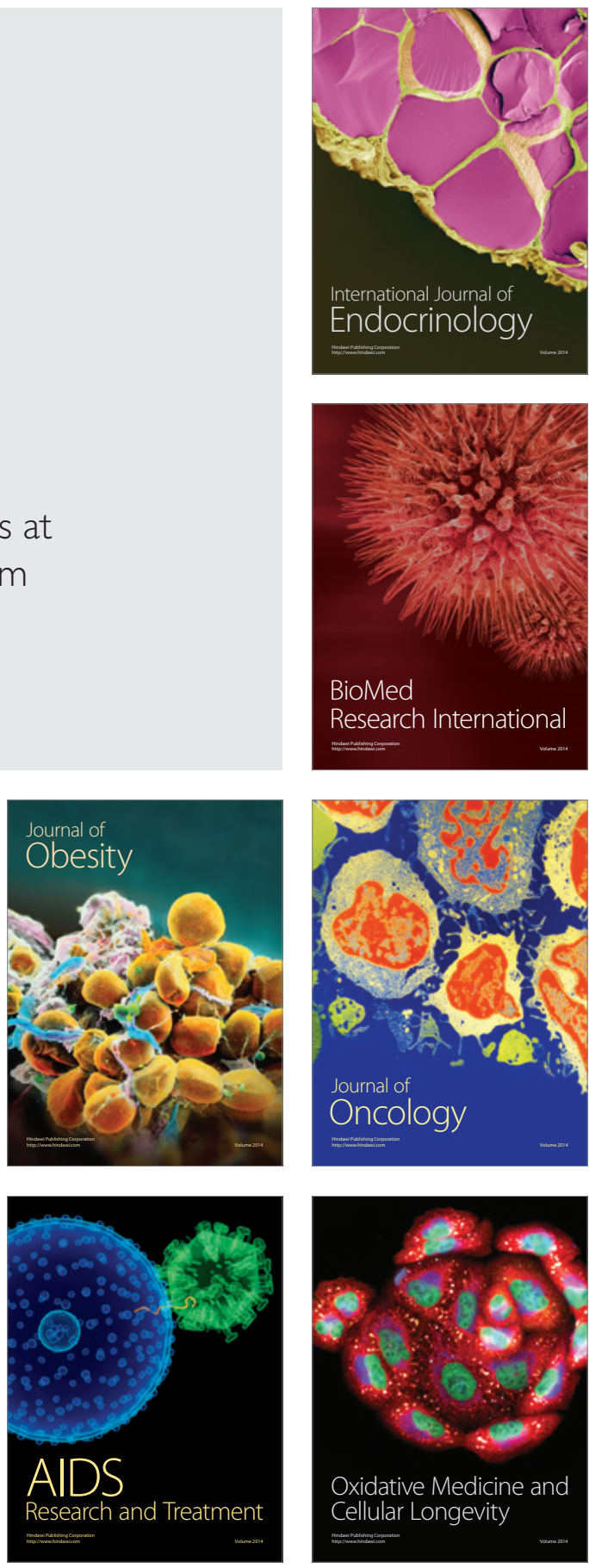